Article

\title{
Preliminary Phytochemical Analysis of Berberis goudotii Triana \& Planch. ex Wedd. (Berberidaceae) with Anticariogenic and Antiperiodontal Activities
}

\author{
Luis G. Sequeda-Castañeda ${ }^{1,2, *} \mathbb{C}$, Camila C. Muñoz-Realpe ${ }^{2} \oplus$, Crispín A. Celis-Zambrano ${ }^{2}$, \\ Sandra J. Gutiérrez-Prieto ${ }^{3}$, Pilar E. Luengas-Caicedo ${ }^{1}$ and Fredy Gamboa ${ }^{3,4, *}$ \\ 1 Department of Pharmacy, Faculty of Sciences, Universidad Nacional de Colombia, 111321 Bogotá, Colombia; \\ peluengasc@unal.edu.co \\ 2 Department of Chemistry, Faculty of Sciences, Pontificia Universidad Javeriana, 110231 Bogotá, Colombia; \\ camila.munoz@javeriana.edu.co (C.C.M.-R.); crispin.celis@javeriana.edu.co (C.A.C.-Z.) \\ 3 Dentistry Research Center, Faculty of Dentistry, Pontificia Universidad Javeriana, 110231 Bogotá, Colombia; \\ s.gutierrez@javeriana.edu.co \\ 4 Department of Microbiology, Faculty of Sciences, Pontificia Universidad Javeriana, 110231 Bogotá, Colombia \\ * Correspondence: 1sequeda@javeriana.edu.co or lgsequedac@unal.edu.co (L.G.S.-C.); \\ gamboa@javeriana.edu.co (F.G.); Tel.: +57-1-3208320 (ext. 4115) (L.G.S.-C.)
}

Received: 17 November 2018; Accepted: 28 December 2018; Published: 12 January 2019

\begin{abstract}
Berberis goudotii is an endemic Colombian plant found in the paramo ecosystem. It has been used in food preparation and as a medicinal plant for diverse treatments. Additionally, it is used as a mouthwash to strengthen the gums and combat throat irritations and periodontitis. The present research evaluated Berberis goudotii aerial parts extract and fractions antimicrobial activities. Ultrasonic-assisted extraction was used to attain total ethanol-water extract. Solid-liquid fractionation was used to obtain hexane fraction. The residue was dispersed in water and liquid-liquid fractionation was carried-out to acquire dichloromethane, butanol and water fractions. Preliminary phytochemical analysis was performed on total extract and phenol, polyphenol, flavonoid, and proanthocyanidin, while tannin content was quantified. Antimicrobial activity assessment was performed by agar diffusion method using disks and wells employing Ceftazidime as a positive control against Streptococcus mutans, Streptococcus sobrinus, Lactobacillus acidophilus, Lactobacillus casei, Porphyromonas gingivalis, Prevotella intermedia and Fusobacterium nucleatum. Antimicrobial activity was determined as relative percentage inhibition (RPI), minimum inhibitory concentration (MIC) and minimum bactericidal concentration (MBC). Phenols (92.5 $\pm 7.7 \mathrm{mg} \mathrm{GA} / 10 \mathrm{~g}$ ), polyphenols $(87.7 \pm 8.1 \mathrm{mg}$ PG/10 g) and tannins $(44.1 \pm 4.3 \mathrm{mg}$ PG/10 g) were among the highest secondary metabolites observed. Total extract presented an MBC of $1.0 \mu \mathrm{g} / \mu \mathrm{L}$ against cariogenic bacteria (Streptococcus mutans and Streptococcus sobrinus) and $0.12 \mu \mathrm{g} / \mu \mathrm{L}$ against bacteria associated with periodontal disease (Porphyromonas gingivalis, Prevotella intermedia and Fusobacterium nucleatum). Butanol and hexane fractions showed antiperiodontal activity with $\mathrm{MBC}$ of 0.12 and $1.0 \mu \mathrm{g} / \mu \mathrm{L}$, respectively. In conclusion, Berberis goudotii total extract demonstrated antimicrobial activity against cariogenic and periodontal microorganisms, on the other hand, hexane and butanol fractions displayed antiperiodontal activity.
\end{abstract}

Keywords: Berberis goudotii; anticariogenic; antiperiodontal; Streptococcus mutans; Streptococcus sobrinus; Lactobacillus acidophilus; Lactobacillus casei; Porphyromonas gingivalis; Prevotella intermedia; Fusobacterium nucleatum; bacteriostatic; bactericide 


\section{Introduction}

Oral diseases are registered as some of the most prevalent and high cost public health concerns, taking into account not only their economic burden, but their impact on the individual's quality of life [1-3]. Worldwide tooth loss is attributed to caries and periodontal disease, which causes chewing dysfunction, malnutrition, low self-esteem and speech difficulties, preventing the individual from social interaction [4]. Dental caries is a disease that initially produces enamel tissue demineralization, followed by tooth decay when acidogenic bacteria, mainly Streptococcus mutans and Lactobacillus acidophilus present in the biofilm remain active in the oral cavity [5-9]. Demineralization ensues when an equilibrium between mineral loss, caused by these microorganisms, and mineral recovery aided by saliva is lost [10]. Periodontal disease is a chronic inflammatory disease affecting the tissue surrounding teeth, resulting in tooth loss [11]. These diseases have been classified as gingivitis, characterized only by gingival mucosa inflammation and periodontitis, where supporting tissue is destroyed, such as gum alveolar bone and periodontal ligament [12]. Its etiology has been associated with biofilm microorganisms, such as Porphyromonas gingivalis, Prevotella intermedia, Fusobacterium nucleatum and Aggregatibacter actinomycetemcomitans [9,13].

At present caries management is based on bacteria biofilm removal by tooth brushing with tooth paste, use of fluorinated substances [14,15] and sealant application, among other options that promote remineralization and preservation of dental tissue [16,17]. In regard to periodontal disease treatment, in addition to traditional protocols, recent studies report on biofilm, endotoxin and contaminated cement removal by scaling and root planning (SRP) $[18,19]$. Various strategies have been proposed to remove pathogens, especially in deep periodontal pockets of difficult access. One of them is a drying agent that allows for easier biofilm removal. It is a safe technique, which diminishes bacterial load, thus reducing inflammation in periodontitis treatment [20-22]. Likewise, other studies propose herbal chlorhexidine in post-surgery protocols, as biofilm inhibitors, providing comfort to the patient after surgery [23]. Other studies demonstrate good outcomes in periodontitis treatment using a combination of diode laser therapy with scaling and SRP [24].

However, another alternative for caries and periodontal disease treatment is based on bacterial activity inhibition by means of medicinal plants. They provide low cost solutions for the community, are less invasive and don't have toxicity associated problems, as is the case of fluoride $[25,26]$. Various studies with plant extracts and secondary metabolites report high antimicrobial activity. As a case in point, macelignan obtained from Myristica fragrans acts against Streptococcus mutans [27-29]. Moreover, antibacterial activity was evidenced with bakuchiol (obtained from Psoralea coryfolia) against Streptococcus mutans, Streptocccus sanguis, Streptococcus salivarus, Streptococcus sobrinus, and Lactobacillus acidophilus [30]. Hwang et al. described very low isopanduratine A inhibitory concentrations, obtained from Kaempferia pandurata acting in very short time, against Streptococcus mutans, Streptococcus sobrinus, Streptocccus sanguis and Streptococcus salivarius [31]. Akhalwaya et al. reported on Spirostachys africana an effect on Streptococcus mutans reduced adhesion, suggesting potential use of this plant in dental caries treatment, periodontal disease and possibly cold sores [32]. Recently, Gamboa et al. reported antimicrobial activities against periodontal disease from Piper marginatum Jacq. and Ilex guayusa Loes extracts and fractions [33].

Colombia has a privileged geographical location, allowing for great biological resource diversity. Thus, some authors have called it the "the cradle of modern ethnobotany" [34]. In 2011 authors such as Bernal et al., reported a total of 2404 medicinal plants, 214 considered exclusive to Colombia, which have been addressed in some ethnobotanical reports and a few studies related to pharmacognosy, phytochemistry and toxicology [35]. As far as we know, Berberis rigidifolia and Berberis goudotii are endemic Colombian plants, commonly known as "Uña de gato", "Espino" or "Tachuelo". They have been used by indigenous, peasant and local communities for treatment or prevention of human or animal pathologies, such as ulcers, spleen swelling, diarrhea, amoebiasis, gastroenteritis, uterine hemorrhages, leishmaniasis, malaria, and rheumatic syndrome. They have also been used for antibacterial and antiprotozoal applications, including to address mouth and/or throat irritations, 
caries and periodontitis. These plants have also been used as febrifuge, hypotensive, diaphoretic, laxative, tonic, and as hemostatic purgative agents [35-38].

To the best of our knowledge, phytochemical analyses and pharmacognosy of the Berberis goudotti species (endemic to Colombia) have not been carried-out. Therefore, this work represents a first approximation to evaluate if the plant shows antimicrobial activity against cariogenic and periodontopathogenic bacteria, in order to support popular medicinal use for oral cavity disease prevention and treatment, such as caries and periodontitis $[35,38]$.

\section{Materials and Methods}

\subsection{Acquisition of Plantspecimens}

Plant samples corresponding to the aerial parts (leaves, stems, flowers and fruits-Figure 1) were collected in good condition without mechanical (trauma, defoliation), biological (leaf damage by herbivores) or microbiological damage (signs or symptoms of phytopathogens). Samples came from the village of Verjón in the municipality of Bogotá (department of Cundinamarca, Colombia). This species was taxonomically identified with voucher No. COL600163 (identified by N. Salinas /2017) at the Colombian National Herbarium.
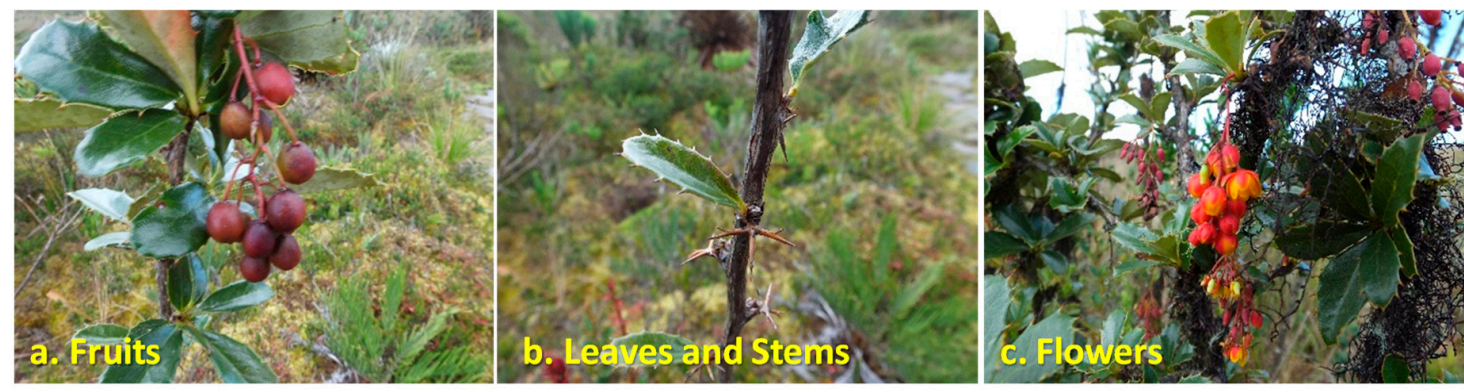

Figure 1. Fruits (a), leaves and stems (b) and flowers (c) from Berberis goudotii Triana \& Plach. [39].

\subsection{Extraction and Fractionation}

Collected material was dried at $40{ }^{\circ} \mathrm{C}$ in an oven with forced air circulation. Dried plant material was ground to a moderately fine particle size. Then, by triplicate, 100 grams of ground material was exposed to ultrasound-assisted extraction (Fischer Ultrasonic, Model 60, $50 \mathrm{kHz}$ ) for $60 \mathrm{~min}(20 \mathrm{~min} \times$ $1 \mathrm{~L} \times 3$ times) using a total of 3.0 liters of ethanol:water (7:3). The extractive solution was concentrated using rotatory-evaporation at $40{ }^{\circ} \mathrm{C}$ and water concentrated extract was lyophilized. $15 \mathrm{~g}$ of dried crude extract were fractionated with solvents. The hexane fraction $\left(\mathrm{C}_{6} \mathrm{H}_{14}, 100 \mathrm{~mL} \times 3\right.$ times $)$ was obtained by solid-liquid fractionation of the extract. The insoluble residue was suspended in $100 \mathrm{~mL}$ of distilled water and fractionated by liquid-liquid fractionation technique, first with dichloromethane $\left(\mathrm{CH}_{2} \mathrm{Cl}_{2}, 100 \mathrm{~mL} \times 3\right.$ times) then with butanol (BuOH, $100 \mathrm{~mL} \times 3$ times). The organic fractions were concentrated using rotatory-evaporation at $40{ }^{\circ} \mathrm{C}$, then evaporated to dryness in a vacuum oven at $40{ }^{\circ} \mathrm{C}$, and finally lyophilized to remove the saturation water residue. The residual water fraction was lyophilized. The extract and all fractions were stored at $-50{ }^{\circ} \mathrm{C}$ in amber bottles [40-43].

\subsection{Preliminary Phytochemical Analysis}

To qualitatively determine secondary metabolites, such as alkaloids, carbohydrates, coumarins, cardiotonic glycosides, steroids and triterpenes, flavonoids, phenols, naphtho- and anthraquinones, saponins, sesquiterpene lactones, tannins, and terpenes in aerial parts (leaves, stems, fruits and flowers) and total extract were subjected to preliminary phytochemical analysis [41,44-48]. Likewise, quantification of several secondary metabolites, such as total phenols (Folin-Ciocalteu method), flavonoids (Aluminum chloride method), proanthocyanidins (Butanol- $\mathrm{HCl}$ assay), polyphenols and tannins (Brazilian Pharmacopoeia method) was carried out $[41,45,49,50]$. 


\subsubsection{Qualitative Determination}

Alkaloids: Dragendorff's test was performed using bismuth iodide and potassium.

Coumarins: Fluoresence test was employed using filter paper and $0.1 \mathrm{~N} \mathrm{NaOH}$ solution.

Cardiotonic glycosides: Kedde test was employed using a mix of 3,5-dinitrobenzoic acid and $10 \%$ $\mathrm{NaOH}$ solution at a 2:1 ratio.

Steroids and triterpenes: Liebermann-Burchard test was employed using acetic anhydride and concentrated sulfuric acid.

Flavonoids: Shinoda's test was employed using magnesium and concentrated hydrochloric acid.

Phenols: $1 \%$ Ferric chloride test.

Naphtho- and anthraquinones: Bornträger-Kraus's test using 20 volume $\mathrm{H}_{2} \mathrm{O}_{2}, 50 \%$ sulfuric acid and $5 \%$ toluene and $5 \% \mathrm{NaOH}$.

Saponins: Froth test was performed using strongly agitated water. If the test was positive, then hemolysis of a red blood cell suspension was performed.

Sesquiterpene lactones: Ferric hydroxamate test using $2 \mathrm{~N}$ hydroxamate hydrochloride, $2 \mathrm{~N} \mathrm{KOH}$ and $0.5 \mathrm{~N} \mathrm{HCl}$, and $1 \%$ ferric chloride.

Tannis: Gelatine-salt test using gelatine-salt reagent, $10 \mathrm{M}$ urea and $1 \%$ ferric chloride.

\subsubsection{Quantitative Determination}

Phenols: Approximately $1.0 \mathrm{~g}$ of ground plant material was weighed and $10 \mathrm{~mL} \mathrm{Me} \mathrm{CO}_{2} \mathrm{CH} \mathrm{H}_{2} \mathrm{O}$ (7:3) was added. Mix was agitated for $30 \mathrm{~min}$, followed by centrifugation during $3 \mathrm{~min}$ at $3000 \mathrm{rpm}$. The extraction process was performed three times. At the end of the processes, supernatants were collected in a $50 \mathrm{~mL}$ volumetric flask and volume was completed with deionized water. Final sample solution was refrigerated at $4{ }^{\circ} \mathrm{C}$, until metabolites were quantified. For the sample corresponding to total extract, a $1000 \mathrm{ppm}$ methanol solution was prepared and stored under refrigeration at $4{ }^{\circ} \mathrm{C}$ [51].

$12 \mu \mathrm{L}$ sample (plant material or extract) as well as $200 \mu \mathrm{L}$ distilled water were added in a microplate. In a dark room $40 \mu \mathrm{L}$ Folin-Ciocalteu reagent (Sigma, St Louis, MO, USA) was added. The mix was agitated and incubated for $3 \mathrm{~min}$ at room temperature (RT). Subsequently, $12 \mu \mathrm{L} 5 \%$ sodium carbonate were added and incubated at $40{ }^{\circ} \mathrm{C}$ for $30 \mathrm{~min}$. Absorbance was read at $740 \mathrm{~nm}$ after 60-min incubation. Gallic acid solutions between 0.50 and $500 \mu \mathrm{g} / \mathrm{mL}$ were used for a standard curve. Results were expressed as mg gallic acid per $10 \mathrm{~g}$ of sample [33,52].

Flavonoids: Approximately $1.0 \mathrm{~g}$ of ground plant material was weighed and $10 \mathrm{~mL} \mathrm{MeOH}$ was added, solution was heated under water reflux for $30 \mathrm{~min}$. Solution was cooled and centrifuged for $3 \mathrm{~min}$ at $3000 \mathrm{rpm}$. The extraction process was carried out three times. At the end of all processes, supernatants were collected in a $100 \mathrm{~mL}$ volumetric flask and volume was completed with methanol [53]. The final sample solution was stored under refrigeration at $4{ }^{\circ} \mathrm{C}$. For a total extract sample, a $1000 \mathrm{ppm}$ methanol solution was prepared and stored under refrigeration at $4{ }^{\circ} \mathrm{C}$.

$125 \mu \mathrm{L}$ sample (plant material or extract) were added in a microplate. In a dark room $125 \mu \mathrm{L}$ $2 \%$ aluminum chloride was added. Mix was agitated and incubated for $15 \mathrm{~min}$ at $40{ }^{\circ} \mathrm{C}$. Absorbance was read at $420 \mathrm{~nm}$ after $60-\mathrm{min}$ incubation. Quercetin solutions between 1.0 and $50 \mu \mathrm{g} / \mathrm{mL}$ were employed as a standard curve. Results were expressed as mg quercetin per $10 \mathrm{~g}$ of sample [33,50].

Proanthocyanidins: Approximately $2.0 \mathrm{~g}$ of ground plant material was weighed and extracted by sonication with $15 \mathrm{~mL} \mathrm{Me} 2 \mathrm{CO}: \mathrm{H}_{2} \mathrm{O}$ (7:3) for $15 \mathrm{~min}$. The extraction process was carried-out three times. The final solution was filtered and volume was completed in a $100 \mathrm{~mL}$ volumetric flask. An extract solution aliquot of $10 \mathrm{~mL}$ was concentrated and $90 \mathrm{~mL} \mathrm{n-BuOH}$ and $37 \% \mathrm{HCl}$ at $95: 5$ ratio was added, and the solution was heated under water reflux for $2 \mathrm{~h}$ at $130^{\circ} \mathrm{C}$. At the end of the process the solution was transferred to a $100 \mathrm{~mL}$ volumetric flask and volume was completed with $\mathrm{n}-\mathrm{BuOH}$ and $37 \% \mathrm{HCl}$ at 95:5 ratio. Final solution absorbance was read at $540 \mathrm{~nm}$ and proanthocyanidins were quantified utilizing the equation 1 :

$$
\% \text { Proanthocyanidins }=(\mathrm{Abs} / \mathrm{M}) \times 4.115
$$


where, Abs is sample absorbance and $M$ is the sample mass in grams [50,54].

For the sample corresponding to the extract, approximately $100 \mathrm{mg}$ were weighed and $10 \mathrm{~mL}$ $\mathrm{Me}_{2} \mathrm{CO}: \mathrm{H}_{2} \mathrm{O}(7: 3)$ were added. The sample was sonicated for $15 \mathrm{~min}$ at $30^{\circ} \mathrm{C}$. Subsequently it was filtered and a final volume of $50 \mathrm{~mL}$ was completed with $\mathrm{Me}_{2} \mathrm{CO}: \mathrm{H}_{2} \mathrm{O}$ (7:3). A $20 \mathrm{~mL}$ aliquot was concentrated using a rotary evaporator at $40{ }^{\circ} \mathrm{C}$. Residue was dissolved in $\mathrm{n}-\mathrm{BuOH}$ and $37 \% \mathrm{HCl}$ at a 95:5 ratio, and the solution was heated under oil reflux for $2 \mathrm{~h}$. The solution was cooled and transferred into a volumetric flask. A final volume of $50 \mathrm{~mL}$ was completed with $\mathrm{n}-\mathrm{BuOH}$ and $37 \% \mathrm{HCl}$ at a 95:5 ratio. Absorbance was read at $540 \mathrm{~nm}$ using as blanc $\mathrm{n}-\mathrm{BuOH}$ and $37 \% \mathrm{HCl}$ at a $95: 5$ ratio of solution. Proanthocyanidins content was expressed as cyanogen chloride using equation 2:

$$
\% \text { Proanthocyanidins }=(\mathrm{Abs} / \mathrm{M}) \times 1.02875
$$

where, \%Proanthocyanidins corresponds to proanthocyanidins percentage, Abs is sample absorbance and $\mathrm{M}$ is the sample mass in grams $[50,53]$.

Polyphenols and tannins: Approximately $250 \mathrm{mg}$ plant material was weighed and $15 \mathrm{~mL}$ deionized water was added. The solution was boiled, followed by water bath incubation at $60^{\circ} \mathrm{C}$ for $30 \mathrm{~min}$. The solution was allowed to cool down and then filtered and transferred to $25 \mathrm{~mL}$ volumetric flask, volume was completed with deionized water (solution $\mathrm{S}_{1}$ ) [53].

For total extract sample approximately $100 \mathrm{mg}$ were weighed, and $5 \mathrm{~mL}$ deionized water was added. Mix was boiled, followed by water bath incubation for $30 \mathrm{~min}$. The solution was allowed to cool down and then filtered and transferred to $10 \mathrm{~mL}$ volumetric flask, the volume was completed with deionized water (solution $\mathrm{S}_{2}$ ) [53].

For total polyphenol quantification $2.5 \mathrm{~mL}$ (solution $\mathrm{S}_{1}$ or $\mathrm{S}_{2}$ ) were taken and $5 \mathrm{~mL}$ deionized water was added in a volumetric flask. A $500 \mu \mathrm{L}$ aliquot was taken and mixed with $200 \mu \mathrm{L}$ Folin-Denis reactive. The volume was completed to $10 \mathrm{~mL}$ with $15 \%$ sodium carbonate $(\mathrm{m} / \mathrm{v})$ in a volumetric flask. Two min after adding sodium carbonate, absorbance $\left(\mathrm{A}_{1}\right)$ was read at $715 \mathrm{~nm}$.

For tannin quantification $2 \mathrm{~mL}$ solution $\mathrm{S}_{1}$ or $\mathrm{S}_{2}$ were taken and $25 \mathrm{mg}$ skin powder were added, the resulting solution was agitated at $200 \mathrm{rpm}$ for $60 \mathrm{~min}$. Following, a dilution was performed with $1 \mathrm{~mL}$ of solution, taking it to a final volume of $2.5 \mathrm{~mL}$. A $500 \mu \mathrm{L}$ aliquot was taken and mixed with $200 \mu \mathrm{L}$ Folin-Denis reactive. The volume was completed to $5 \mathrm{~mL}$ with $15 \%$ sodium carbonate $(\mathrm{m} / \mathrm{v})$ in volumetric flask. Two min after adding sodium carbonate, absorbance $\left(\mathrm{A}_{2}\right)$ was read at $715 \mathrm{~nm}$.

As a standard $5 \mathrm{mg}$ pyrogallol (Sigma, St Louis, MO, USA) was dissolved in $10 \mathrm{~mL}$ deionized water. $500 \mu \mathrm{L}$ aliquot was taken and completed to a final volume of $10 \mathrm{~mL}$. A $500 \mu \mathrm{L}$ aliquot was transferred to a $5 \mathrm{~mL}$ volumetric flask and $200 \mu \mathrm{L}$ Folin-Denis reactive was added and volume was completed with $15 \%$ sodium carbonate $(\mathrm{m} / \mathrm{v})$ solution. Two min after adding sodium carbonate, absorbance $\left(\mathrm{A}_{3}\right)$ was read at $715 \mathrm{~nm}$.

Polyphenol percentage (PP) and tannin percentage (T) were expressed as percentages using the following equations: For $\% \mathrm{PP}$ for $\mathrm{S}_{1}$ solution equation 3 . For $\% \mathrm{~T}$ for $\mathrm{S}_{1}$ solution equation 4 . For $\% \mathrm{PP}$ for $S_{2}$ solution equation 5. For \% $\mathrm{T}$ for $S_{2}$ solution equation 6 .

$$
\begin{gathered}
\% \mathrm{PP}=\left(6.56 \times \mathrm{A}_{1}\right) /\left(\mathrm{A}_{3} \times \mathrm{M}\right) \\
\% \mathrm{~T}=6.56 \times\left(\mathrm{A}_{1}-\mathrm{A}_{2}\right) /\left(\mathrm{A}_{3} \times \mathrm{M}\right) \\
\% \mathrm{PP}=\left(2.624 \times \mathrm{A}_{1}\right) /\left(\mathrm{A}_{3} \times \mathrm{M}\right) \\
\% \mathrm{~T}=2.624 \times\left(\mathrm{A}_{1}-\mathrm{A}_{2}\right) /\left(\mathrm{A}_{3} \times \mathrm{M}\right)
\end{gathered}
$$

where, $M$ is sample quantity in grams, $A_{1}$ is sample absorbance without treatment, $A_{2}$ is sample absorbance with treatment and $A_{3}$ is pyrogallol absorbance as a standard $[49,53]$. 


\subsection{Anticariogenic and Antiperiodontal Activity}

Anticariogenic and antiperiodontal activity was determined for total extract and its fractions using the agar diffusion technique per disc and per well [55-59]. Each assay was performed in biological and technical triplicates, $(n=3)$. A susceptibility screening for antimicrobials (antibiogram) was performed to select the positive control among 18 commercial antibiotics: amoxicillin/clavulanic acid $(20 / 10 \mu \mathrm{g})$, optoquinone $(5 \mu \mathrm{g})$, penicillin $(10 \mu \mathrm{g})$, clindamycin $(2 \mu \mathrm{g})$, ceftazidime $(30 \mu \mathrm{g})$, ampicillin/sulbactam $(10 / 10 \mu \mathrm{g})$, cefalotin $(30 \mu \mathrm{g})$, novobiocin $(30 \mu \mathrm{g})$, oxacillin $(1 \mu \mathrm{g})$, bacitracin $(0.04 \mu \mathrm{g})$, erythromycin $(15 \mu \mathrm{g})$, chloramphenicol $(30 \mu \mathrm{g})$, vancomycin $(30 \mu \mathrm{g})$, streptomycin $(10 \mu \mathrm{g})$, gentamicin $(10 \mu \mathrm{g})$, amikacin $(30 \mu \mathrm{g})$, ampicillin $(10 \mu \mathrm{g})$ and amoxicillin $(10 \mu \mathrm{g})$. As negative controls, $\mathrm{C}_{6} \mathrm{H}_{14}, \mathrm{CH}_{2} \mathrm{Cl}_{2}$, $\mathrm{BuOH}$ and DMSO were used [59].

\subsection{Microorganisms}

Evaluation of anticariogenic and antiperiodontal activity was performed using certified strains. Cariogenic bacteria; Lactobacillus acidophilus (ATCC 4365), Lactobacillus casei (ATCC 4646), Streptococcus mutans (ATCC 25175), Streptococcus sobrinus (ATCC 33478) and periodontal bacteria; Fusobacterium nucleatum (ATCC 25586), Porphyromonas gingivalis (ATCC 33277), Prevotella intermedia (ATCC 25611) were purchased from the American Type Culture Collection (ATCC) by the Center for Dental Research at the Pontificia Universidad Javeriana. Glycerol (25\%) was used for strain conservation and storage at $-70{ }^{\circ} \mathrm{C}$. These conditions were necessary to maintain the genetic characteristics and bacterial resistance throughout the study.

\subsection{Inoculum Preparation for Cariogenic Bacteria}

All strains were reactivated under anaerobic conditions $\left(\mathrm{H}_{2}: \mathrm{CO}_{2}: \mathrm{N}_{2}, 10: 10: 80\right)$ using BHI broth for $12 \mathrm{~h}$ at $37^{\circ} \mathrm{C}$. Bacteria grown in the BHI broth were plated on blood agar and incubated for $48 \mathrm{~h}$ at $37^{\circ} \mathrm{C}$ in an anaerobic atmosphere $\left(\mathrm{H}_{2}: \mathrm{CO}_{2}: \mathrm{N}_{2}, 10: 10: 80\right)$. Pure, viable colonies were reconfirmed using Gram stain and biochemical tests. From a pure culture of each strain to be evaluated, a suspension was prepared in BHI broth adjusted by turbidometry to a $0.5 \mathrm{McFarland}$ standard $\left(1.5 \times 10^{8}\right.$ cells $\left./ \mathrm{mL}\right)$ [60].

\subsection{Inoculum Preparation for Periodontal Bacteria}

Thioglycate broth (BBL ${ }^{\mathrm{TM}}$ Fluid, Becton Dickinson and Company) supplemented with hemine and menadione was added to lyophilized strains and incubated at $37^{\circ} \mathrm{C}$ for 8 days under anaerobic conditions $\left(\mathrm{H}_{2}: \mathrm{CO}_{2}: \mathrm{N}_{2}, 10: 10: 80\right)$. Then, isolation was carried-out using blood agar and Wilkins-Chalgren (Oxoid) anaerobic agar supplemented with $1 \%(v / v)$ hemin and menadione at $37^{\circ} \mathrm{C}$ for 8 days under anaerobic conditions $\left(\mathrm{H}_{2}: \mathrm{CO}_{2}: \mathrm{N}_{2}, 10: 10: 80\right)$. Then, isolation was performed using blood agar and Wilkins-Chalgren (Oxoid) anaerobic agar supplemented with $1 \%(v / v)$ hemin and menadione and incubated at $37^{\circ} \mathrm{C}$ for 8 days under anaerobic conditions $\left(\mathrm{H}_{2}: \mathrm{CO}_{2}: \mathrm{N}_{2}, 10: 10: 80\right)$. Finally, obligate anaerobic colonies were selected, and their purity was confirmed by Gram stain. Pure isolates of obligate anaerobes were identified with the RapID ${ }^{\mathrm{TM}}$ ANA II system (Remel). Inoculum was obtained by taking 5 morphologically identical colonies from each bacterium and then they were suspended in $5 \mathrm{~mL}$ of BHI broth enriched with Hemin $(5 \mu \mathrm{g} / \mathrm{mL})$ and Menadione $(1 \mu \mathrm{g} / \mathrm{mL})$ and incubated for 5 days at $37^{\circ} \mathrm{C}$ in anaerobiosis $\left(\mathrm{H}_{2}: \mathrm{CO}_{2}: \mathrm{N}_{2}, 10: 10: 80\right)$. Suspension was then adjusted to the McFarland 0.5 scale $\left(1.5 \times 10^{8}\right.$ cells $\left./ \mathrm{mL}\right)$ [58].

\subsection{Agar Diffusion Methods-Disk and Well}

For cariogenic bacteria, $250 \mu \mathrm{L}$ microorganism suspension was mixed with $25 \mathrm{~mL}$ of Mueller-Hinton agar and poured into a Petri dish. For periodontal bacteria, $250 \mu \mathrm{L}$ microorganism suspension was mixed with $25 \mathrm{~mL}$ of Wilkins-Chalgren anaerobic agar supplemented with $1 \%(v / v)$ hemin and menadione. For the disk diffusion method, blank Oxoid discs were taken and placed on Mueller-Hinton and Wilkins-Chalgren media [57]. For agar diffusion method per well (Mueller-Hinton 
and Wilkins-Chalgren agars), wells were perforated ( $6.0 \mathrm{~mm}$ diameter), in each well $25 \mu \mathrm{L}$ of extract or fraction were dosed at concentrations ranging from 1.0 to $50 \mu \mathrm{g} / \mu \mathrm{L}$. $25 \mu \mathrm{L}$ of DSMO, $\mathrm{C}_{4} \mathrm{H}_{6}, \mathrm{CH}_{2} \mathrm{Cl}_{2}$, $\mathrm{BuOH}$ and $\mathrm{H}_{2} \mathrm{O}$ were used as negative controls and $25 \mu \mathrm{L}$ of ceftazidime $(30 \mu \mathrm{g})$, as a positive control. All Petri dishes were incubated under anaerobic conditions for $48 \mathrm{~h}$ at $37^{\circ} \mathrm{C}$ for cariogenic bacteria and 8 days at $37^{\circ} \mathrm{C}$ for periodontal bacteria [59]. Inhibition halos were measured (mm) and the antimicrobial activity was determined as a relative percentage of the inhibition (RPI) using as a positive control the selected antibiotic chosen from the antibiogram using the formula:

$$
\mathrm{RPI}=[(\mathrm{Di}-\mathrm{Dn}) /(\mathrm{Dp}-\mathrm{Dn})] \times 100
$$

where, Di is the diameter of the inhibition zone of the extract or fraction, Dn is the inhibition zone diameter of the negative control and $\mathrm{Dp}$ is diameter of the positive control inhibition zone [61].

\subsection{Minimum Inhibitory Concentration-Minimum Bactericidal Concentration}

Minimum inhibitory concentration (MIC) is defined as the lowest concentration of the antimicrobial agent that inhibits visible growth of a microorganism under defined conditions. For this purpose, broth microdilution and agar diffusion techniques were used [59,62,63]. Total extract and fractions ranged between 0.06 and $32 \mu \mathrm{g} / \mu \mathrm{L}$. A microplate reader was used for the microdilution technique $\left(\mathrm{OD}_{600}\right)$ using 96-well plates and each well. $5 \mu \mathrm{L}$ of the inoculum were added along with $220 \mu \mathrm{L}$ BHI broth (for cariogenic microorganisms) or Wilkins-Chalgren broth (for periodontal bacteria), then $25 \mu \mathrm{L}$ of each extract or fraction were added and incubated for $48 \mathrm{~h}$ (for cariogenic microorganisms) and 8 days (for periodontal bacteria) under anaerobic conditions at $37^{\circ} \mathrm{C}$. For the agar diffusion technique, $25 \mu \mathrm{L}$ of the extract or fraction were taken and placed in $6 \mathrm{~mm}$ wells with BHI (for cariogenic bacteria) or Wilkins-Chalgren (for periodontal microorganisms) agars, previously inoculated with each microorganism. Once MIC was determined, reseeding was performed with two different concentrations, one above and one below MIC to evaluate extract and fraction bacteriostatic or bactericidal effect. Extract and fraction minimum bactericidal concentration (MBC) was determined based on the one, which did not allow visible growth of colonies in the Petri dish. If colony growth was observed, then the extract or fraction at the evaluated concentration was described to produce a bacteriostatic effect, in contrast to a bactericidal effect [64-66].

\subsection{Statistical Analysis}

All experiments were performed in triplicates $(n=3)$. Results are expressed as means \pm standard deviations [67]. Subsequently, a completely randomized design was developed, for which parametric statistic compliance assumptions was determined by performing normality tests (Shapiro-Wilks) and homogeneity of variance (Levenne). An analysis of variance (ANOVA) was carried out with Tukey's HSD post hoc comparison test of means to determine significant differences. For the data that did not fulfill the assumptions, transformations were performed (square root, natural logarithm, logarithm in base ten and reciprocal). Tests were performed using InfoStat/P software [67-70].

\section{Results and Discussion}

\subsection{Extraction and Fractionation}

In this study ultrasound-assisted extraction (UAE) was used to obtain Berberis goudotii total EtOH: $\mathrm{H}_{2} \mathrm{O}$ (7:3) extract [71,72]. This type of extraction (UAE) was used because it is a clean, efficient, economical, simple and environmentally friendly method, compared with the traditional techniques used to obtain raw extracts [73-75]. Likewise, UAE increases the content of potentially active compounds in raw extracts [76-80].

Total extract yield (based on dried herbal material mass) was $18.6 \pm 1.6 \%$. Since our study initiated with the Berberis goudotii phytochemical analysis, there is no information for result comparison. 
However, when comparing with other species of the Berberis genus such as Berberis koreana, extraction processes yields have been reported to be $8.4 \%$ with conventional extraction, 11.04\% using high pressure extraction (HPE) and 12.3\% for high pressure extraction with sonication (HPEWS) [81,82]. Using maceration and methanol techniques for Berberis aetnensis and Berberis libanotica extraction yields were 8.9 and $7.6 \%$, respectively, as specified by Bonesi [83]. Likewise, for Berberis jaeschkeana a $4.5 \%$ extraction yield was described when using maceration with methanol [84]. For Berberis darwinii yields were 9.5 and $1.5 \%$ by maceration and infusion using methanol and water respectively [85]. For Berberis tabienses a yield of $9.5 \%$ was obtained, using the percolation method and ethanol [86]. Yields greater than $50 \%$ were found for Berberis vulgaris (52.4\%) and Berberis croatica (52.1\%) using 96\% ethanol and UAE [72].

The calculated process yield was taken as a reference crude extract mass used for the fractionation. The highest extraction yield for the fractions was $\mathrm{CH}_{2} \mathrm{Cl}_{2}$ fraction $(16.4 \pm 3.1 \%)$, followed by $\mathrm{C}_{6} \mathrm{H}_{14}(9.7$ $\pm 2.7 \%), \mathrm{BuOH}(7.2 \pm 1.4 \%)$ and $\mathrm{H}_{2} \mathrm{O}(4.2 \pm 1.2 \%)$ fractions, respectively. No significant differences were observed $(p>0.01)$ between $\mathrm{C}_{6} \mathrm{H}_{14}$ and $\mathrm{CH}_{2} \mathrm{Cl}_{2}$ fractions. Also, between $\mathrm{BuOH}$ and $\mathrm{H}_{2} \mathrm{O}$ fractions, no significant differences were recognized. Significant differences were only detected $(p<0.01)$ between $\mathrm{CH}_{2} \mathrm{Cl}_{2}$ fraction and $\mathrm{BuOH}$ and $\mathrm{H}_{2} \mathrm{O}$ fractions (see Figure 2), suggesting that medium polar metabolites were more abundant in the Berberis goudotii extract (see Figure 2).

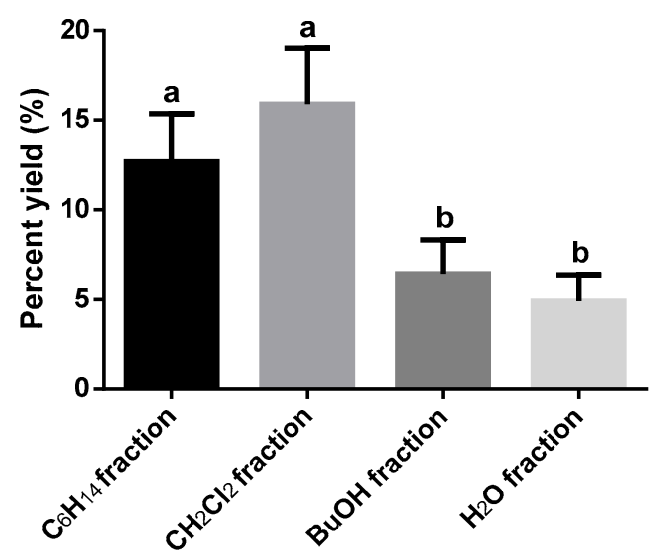

Figure 2. Berberis goudotii extract fractionated (Yields percent). $n=3$ determinations. ANOVA with Tukey HSD test post hoc was used to identify differences between groups, means with the same letter are not significantly different $(p>0.01)$. Total dry extract yield $=18.6 \pm 1.6 \%$.

\subsection{Preliminary Phytochemical Analysis}

Total extract qualitative phytochemical analysis revealed the presence of alkaloids, flavonoids, phenols, tannins, steroids and terpenes, as well as absence of coumarins, cardiotonic glycosides, naptho- and anthraquinones and sesquiterpenlactones (Table 1).

For Berberis genus protoberberins, isoquinoline, and bisbenzylisoquinoline alkaloids were present in greater quantities in root and bark [87-91]. In contrast, terpenes, anthocyanins, tannins and phenolic compounds have been found in leaves and fruits of Berberis vulgaris [92,93]. Coumarins and phytosterols have been identified from Berberis lycum roots [94]. Total phenols and flavonoids were found in Berberis aetnensis, Berberis croatica and Berberis libanotica roots, and Berberis microphylla fruits $[72,83,95]$. The presence of total phenols, flavonoids and tannins were reported for Berberis jaeschkeana and Berberis microphylla fruits, and Berberis asiatica leaves [71,95,96]. Alkaloids and saponins were reported for Berberis microphylla fruits [95].

Considering the presence of phenolic compounds and their antibacterial activity, in this work several phenolic metabolite classes were quantified in the dried aerial parts (leaves, stems, flowers and fruits) and in the dried hydroethanolic extract. In all cases the quantities reported for 10 grams of sample were as follows: milligrams of gallic acid (GA) for phenols, milligrams of pyrogallol (PG) for polyphenols and tannins, milligrams of quercetin (QE) for flavonoids, and milligrams of 
cyanidin (CI) for proanthocyanidins (Table 1). In all cases the extract contained at least double the quantity of phenolic metabolites compared to the herbal material, where the largest metabolites concentration was observed for total tannins with a 2.9 ratio. The extraction process performance was efficient, due to the solvent being used having a higher content of secondary metabolites in the extract than in the herbal material used to prepare the extract [53]. As expected, global phenolic classes (phenols and polyphenols) presented larger quantities than specific classes like flavonoids, tannins and proanthocyanidins. A larger P/E ratio for total tannins (2.9) than for proanthocyanidins (2.2) when using different methodologies suggested the presence of hydrolysable and condensed tannins in Berberis goudotii.

Table 1. Berberis goudotii preliminary phytochemical analysis and phenolic metabolite quantification.

\begin{tabular}{|c|c|c|c|}
\hline Metabolite Class (Test) & Positive, If & Result & Comments \\
\hline Alkaloids (Dragendorff's test) & Precipitated orange & + & Little precipitation \\
\hline Coumarins (Fluorescence test) & Blue or green fluorescence & - & - \\
\hline Cardiotonic glycosides (Kedde's test) & Blue or violet color & - & - \\
\hline $\begin{array}{l}\text { Steroids and triterpenes } \\
\text { (Liebermann-Burchard test) }\end{array}$ & $\begin{array}{l}\text { Blue or green color Purple } \\
\text { color }\end{array}$ & + & $\begin{array}{l}\text { Purple, possibly } \\
\text { triterpenes }\end{array}$ \\
\hline Flavonoids (Shinoda's test) & Red, orange, or violet color & + & Red, possibly flavones \\
\hline Phenols (Ferric chloride test) & Green, blue, or black color & + & $\begin{array}{l}\text { Blue, possibly derived } \\
\text { from pyrogallol }\end{array}$ \\
\hline $\begin{array}{l}\text { Naphtho- and anthraquinones } \\
\text { (Bornträger-Kraus's test) }\end{array}$ & Intense red color & - & 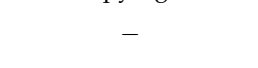 \\
\hline Saponins (Foam and hemolysis test) & $\begin{array}{l}\text { Formation of stable foam. } \\
\text { Hemolysis }\end{array}$ & - & - \\
\hline $\begin{array}{c}\text { Sesquiterpene lactones (Ferric } \\
\text { hydroximate test) }\end{array}$ & Violet or coffee color & - & - \\
\hline Tannis (Gelatine-salt test) & White precipitate & + & Precipited \\
\hline \multicolumn{4}{|c|}{ Phenolic Metabolite Quantification } \\
\hline Metabolite Class & Aerial Parts (P) & Extract (E) & P/E Relation \\
\hline Phenols (mg GA/10 g) & $41.1 \pm 3.3^{a, y}$ & $92.5 \pm 7.7^{b, z}$ & 2.3 \\
\hline Polyphenols (mg PG/10 g) & $38.4 \pm 2.9^{a, y}$ & $87.7 \pm 8.1^{\mathrm{b}, \mathrm{z}}$ & 2.3 \\
\hline Flavonoids (mg QE/10 g) & $10.1 \pm 1.2^{\mathrm{a}, \mathrm{u}}$ & $24.8 \pm 1.5^{\mathrm{b}, \mathrm{x}}$ & 2.5 \\
\hline Proanthocyanidins (mg CI/10 g) & $4.3 \pm 0.5^{\mathrm{a}, \mathrm{t}}$ & $9.5 \pm 1.2^{\mathrm{b}, \mathrm{u}}$ & 2.2 \\
\hline Tannins (mg PG/10 g) & $15.1 \pm 1.7^{\mathrm{a}, \mathrm{v}}$ & $44.1 \pm 4.3^{b, y}$ & 2.9 \\
\hline
\end{tabular}

(+) Presence. $(-)$ Absence. GA = Gallic acid. PG = Pyrogallol. QE = Quercetin. $\mathrm{CI}=$ Cyanidine. ANOVA with Tukey HSD test post hoc was used to identify differences between columns $(a, b)$ and between rows $(t, u, v, x, y, z)$. Means with different letters are significantly different $(p<0.01)$.

Phenolic metabolites quantities found in aerial parts of Berberis goudotii were less than the reported for other Berberis species. Zovko Koncic and collaborators [72] described total phenol content in leaves, small branches and roots of Berberis vulgaris quantified as 52.5, 12.5 and $10.3 \mathrm{mg}$ of GA/g, respectively, and total flavonoids as 4.2, 0.5 and $0.2 \mathrm{mg}$ of quercetin/g, respectively. In the roots of Berberis aetnensis and Berberis libanotica flavonoids (16.2 and $31.5 \mathrm{mg}$ chlorogenic acid/g) and phenols (37.4 and $69.1 \mathrm{mg}$ quercetin/g) were quantified [83]. Likewise, the content in Berberis jaeschkeana fruit tannins (32.4 mg tannic acid/g), flavonoids (188.4 mg quercetin/g) and total phenols (108.9 mg GA/g) have been determined [71]. Arena et al. found in Berberis microphylla fruit monomeric anthocyanins $(9.7 \mathrm{mg} / \mathrm{g})$, $7.6 \mathrm{mg}$ catechin/g for flavonoids and $31.2 \mathrm{mg}$ tannic acid/g for polyphenols [95]; for the same species, $39 \mathrm{mg} / \mathrm{g}$ of alkaloids were identified in root, $5 \mathrm{mg} / \mathrm{g}$ flavonoids, $95 \mathrm{mg} / \mathrm{g}$ tannins and $35 \mathrm{mg} / \mathrm{g}$ saponins [97]. In another work, Bewal and colleagues reported for Berberis asiatica leaves $132.6 \mathrm{mg}$ of $\mathrm{GA} / \mathrm{g}, 31.4 \mathrm{mg}$ of quercetin/g and $145.2 \mathrm{mg}$ of tannic acid/g for total phenols, total flavonoids and total tannins, respectively [96].

Several authors have established that compounds, such as phenols, polyphenols, flavonoids, proanthocyanidins and tannins, have antimicrobial activity $[46,98,99]$. These properties arise from polyphenol and tannin capacity to inhibit enzymes and alter membrane characteristics. Enzyme inhibition by phenols results from compound oxidation, possibly through sulfhydryl group reaction with or through nonspecific protein interactions. Flavonoids can cause cell membrane disruption, and form complexes with soluble and extracellular proteins as well as with membrane walls [46,99]. 


\subsection{Anticariogenic and Antiperiodontal Activities}

Due to antimicrobial screening results, ceftazidime $(30 \mu \mathrm{g})$ was selected as a positive control. Ceftazidime is a beta-lactam antibiotic of the cephalosporins group and is considered a third-generation antibiotic of broad spectrum against Gram-positive and Gram-negative bacteria. Its mechanism of action is by cell wall and bacterial septum inhibition, probably by acylation of transpeptidases linked to the membrane, inhibiting cell division and growth $[100,101]$. This antibiotic is recommended by the Clinical and Laboratory Standards Institute (CLSI), the British Society for Antimicrobial Chemotherapy (BSAC) and Swedish Reference Group for Antibiotics (SRGA) [102]. The negative controls $\left(\mathrm{C}_{6} \mathrm{H}_{14}\right.$, $\mathrm{CH}_{2} \mathrm{Cl}_{2}, \mathrm{BuOH}$, DMSO and $\mathrm{H}_{2} \mathrm{O}$ ) did not show activity against the microorganisms evaluated.

In this work the antimicrobial activity of Berberis goudotii extracts and fractions on cariogenic microorganisms (Streptococcus mutans, Streptococcus sobrinus, Lactobacillus acidophilus, Lactobacillus casei) and periodontal disease (Porphyromonas gingivalis, Prevotella intermedia and Fusobacterium nucleatum) was evaluated. To this end, agar diffusion methods by well and disk were employed [103]. Cariogenic and periodontal disease bacteria employed in this study were obtained from reference strains.

Berberis goudotii antimicrobial activity for total extract and fractions was only observed when well agar diffusion method was used. Dichloromethane and aqueous fractions did not show activity (see Table 2).

Table 2. Antimicrobial activity from total extract and bioactive fractions from Berberis goudotii $(\mu \mathrm{g} / \mu \mathrm{L})$ *

\begin{tabular}{|c|c|c|c|c|c|c|c|c|c|}
\hline \multirow{2}{*}{ Microorganism } & \multicolumn{3}{|c|}{ Total Extract $(\mu \mathrm{g} / \mu \mathrm{L})$} & \multicolumn{3}{|c|}{ Hexane Fraction $(\mu \mathrm{g} / \mu \mathrm{L})$} & \multicolumn{3}{|c|}{ Butanol Fraction $(\mu \mathrm{g} / \mu \mathrm{L})$} \\
\hline & 50 & 25 & 1 & 50 & 25 & 1 & 50 & 25 & 1 \\
\hline L. acidophilus & - & - & - & - & - & - & - & - & - \\
\hline L. casei & - & - & - & - & - & - & - & - & - \\
\hline S. mutans & $\underset{\mathrm{a}, \mathrm{b}}{51.2 \pm 6.3}$ & $\begin{array}{c}36.2 \pm 5.7 \\
\text { b,c,d,e,f }\end{array}$ & - & - & - & - & - & - & - \\
\hline S. sobrinus & $\begin{array}{c}38.8 \pm 5.7 \\
\mathrm{a}, \mathrm{b}, \mathrm{c}, \mathrm{d}, \mathrm{e}\end{array}$ & $\underset{\mathrm{e}, \mathrm{f}, \mathrm{g}}{23.5 \pm 3.2}$ & - & - & - & - & - & - & - \\
\hline F. nucleatum & $\underset{\mathrm{a}, \mathrm{b}, \mathrm{c}, \mathrm{d}}{40.6 \pm 6.4}$ & $\begin{array}{c}28.3 \pm 4.5 \\
\mathrm{~d}, \mathrm{e}, \mathrm{f}, \mathrm{g}\end{array}$ & $\begin{array}{c}19.7 \pm \\
3.8^{\mathrm{g}}\end{array}$ & $\begin{array}{l}28.8 \pm \\
3.0^{t, u, v}\end{array}$ & $\begin{array}{l}20.8 \pm \\
1.5^{\mathrm{v}, \mathrm{x}, \mathrm{y}}\end{array}$ & $\underset{y, z}{12.9 \pm 2.5}$ & $33.8 \underset{t}{ \pm} 2.0$ & $\underset{\mathrm{t}, \mathrm{u}}{30.0 \pm 3.8}$ & $\underset{u, v, x, y}{21.5}=3.6$ \\
\hline P. gingivalis & $\underset{\mathrm{a}, \mathrm{b}, \mathrm{c}}{46.5 \pm 4.5}$ & $\begin{array}{c}25.1 \pm 3.1 \\
\mathrm{~d}, \mathrm{e}, \mathrm{f}, \mathrm{g}\end{array}$ & $\begin{array}{c}17.9 \pm \\
1.9 \mathrm{~g}\end{array}$ & $\begin{array}{c}22.3 \pm \\
1.2^{\mathrm{u}, \mathrm{v}, \mathrm{x}}\end{array}$ & $\begin{array}{l}16.1 \pm \\
2.4^{x, y, z}\end{array}$ & $7.9 \pm 1.6$ & $\underset{t, u, v}{28.1 \pm 2.2}$ & $\begin{array}{c}22.9 \pm 2.4 \\
u, v, x\end{array}$ & $\begin{array}{c}16.0 \pm 2.6 \\
x, y, z\end{array}$ \\
\hline P. intermedia & $\begin{array}{c}53.3 \pm 6.2 \\
\mathrm{a}\end{array}$ & $\begin{array}{c}32.3 \pm 2.4 \\
\mathrm{c}, \mathrm{d}, \mathrm{e}, \mathrm{f}, \mathrm{f}, \mathrm{g}\end{array}$ & $\begin{array}{c}22.1 \pm \\
4.1^{\mathrm{f}, \mathrm{g}}\end{array}$ & $\begin{array}{c}35.2 \pm \\
3.5^{\mathrm{s}, \mathrm{t}}\end{array}$ & $\begin{array}{c}24.6 \pm \\
1.5^{\mathrm{u}, \mathrm{v}, \mathrm{x}}\end{array}$ & $\underset{x, y}{17.2 \pm 0.9}$ & $\underset{\mathrm{s}}{43.3 \pm 2.9}$ & $\underset{t, u, v}{28.1 \pm 1.6}$ & $\underset{x, y}{19.1 \pm 2.7}$ \\
\hline
\end{tabular}

* Agar diffusion method by well. Activity measured as relative percentage of inhibition. Positive control Ceftazidime $(30 \mu \mathrm{g})$. Dichloromethane and aqueous fractions did not present activity. $n=3$ ANOVA with Tukey HSD test post hoc was used to identify differences between columns for total extract $(\mathrm{a}, \mathrm{b}, \mathrm{c}, \mathrm{d}, \mathrm{e}, \mathrm{f}, \mathrm{g})$ and among columns for bioactive fractions $(\mathrm{s}, \mathrm{t}, \mathrm{u}, \mathrm{v}, \mathrm{x}, \mathrm{y}, \mathrm{z})$. Means with different letter were significantly different $(p<0.01)$.

The Ibero-American Program of Science and Technology for Development (CYTED) recommends use of the disk diffusion method [104], due to its reproducibility. Nonetheless, to observe anaerobic microorganism susceptibility, authors such as Olsson and colleagues consider this method inappropriate. They estimate slow growing bacteria and antimicrobial substance concentrations are unsuitable, because the antimicrobial agent around the disk will not be present when bacteria initiate their growth phase [102]. Additionally, natural product extracts and fractions are complex in their composition, since they are a mixture of many compounds with structural diversities. Therefore, there are differences in intermolecular forces; some of these forces are responsible for retaining compounds within the disk. Paper disc composition is exclusively made of cellulose, a homopolymer of $\beta$-glucose molecules. Each $\beta$-glucose has free hydroxyl groups making the surface of the disk hydrophilic, and each hydroxyl provides hydrogen-bond type interactions. This type of intermolecular forces retains or absorbs polar compounds on the surface of the disk, preventing diffusion of compounds in the agar $[105,106]$. This could explain why agar diffusion method using disks presented no activity in this study.

Results suggest the agar diffusion method was more sensitive for natural products compared with the disc diffusion method. The response by agar diffusion method was associated with total extract solubility and DMSO fractions, since DMSO displayed diffusion on solid agar carrying 
along compounds responsible for antimicrobial activity. Diffusion is a physical irreversible process, where matter particles are introduced in a media, initially lacking them, augmenting entropy within the formed system by the diffused particles (DMSO and extract or fractions) and the media where they are diffused (solid agar). Diffusion is the movement of particles in an area, from an area of higher concentration to an area of lower concentration until equilibrium is reached [107].

Diffusion depends on numerous factors including molecule number, size and shape. Particle number is an important factor: molecules diffuse more rapidly at a greater concentration gradient. Particle volume also influences diffusion velocity: small particles diffuse more rapidly and large ones diffuse more slowly. With an increasing molecule radius ( $r$ ), diffusion is expected to decrease proportionately to the $r^{2}$, due to an increase in solute-solvent interaction. Additionally, with increasing temperatures, diffusion is enhanced, due to increased molecule mean kinetic energy. Time is another parameter having an effect on diffusion velocity: mean diffusion distance varies according to the square root of time [108]. Therefore, overnight incubation of agar containing Petri dishes with solubilized extract can increase natural product diffusion. The inoculated system (Petri dish) remains inactive at $2-4{ }^{\circ} \mathrm{C}$ during $12-16 \mathrm{~h}$ before $37^{\circ} \mathrm{C}$ incubation. This process helps in obtaining better detection limits (sensibility) [109].

Therefore, data from our work demonstrated that when working with natural products, it is necessary to carry out more than one method to corroborate if extracts and plant fractions have antimicrobial activity $[105,106,108,110-112]$.

Berberis goudotii total extract and active fractions (hexane and butanol) antimicrobial activity, measured as relative inhibition percentage (RPI) data are presented in Table 2. Moreover, results obtained from minimum inhibitory concentration (MIC) are described in Table 3. Last, total extract and bioactive fractions bactericidal or bacteriostatic effects are exemplified in Table 3. Some authors report this effect as minimum bactericidal concentration (MBC) $[64,66,113]$. In contrast to disk diffusion method, we observed that Berberis goudotii total extract presented anticariogenic activity against Streptococcus mutans with concentrations of 25 and $50 \mu \mathrm{g} / \mu \mathrm{L}$ with an RPI of $36.2 \pm 5.7$ and $51.2 \pm 6.3 \%$ respectively. Bactericidal activity against Streptococcus sobrinus for total extract at $25 \mu \mathrm{g} / \mu \mathrm{L}$ presented a $23.5 \pm 3.2 \%$ RPI and at $50 \mu \mathrm{g} / \mu \mathrm{L}$ a $38.8 \pm 5.7 \%$ RPI. Similarly, total extract exhibited antiperiodontal activity against Fusobacterium nucleatum, Porphyromonas gingivalis and Prevotella intermedia for all concentrations evaluated ( 1 to $50 \mu \mathrm{g} / \mu \mathrm{L}$ ). The highest observed activity was against Prevotella intermedia with RPI values of $22.1 \pm 4.1,32.3 \pm 2.4$ and $53.3 \pm 6.2 \%$ for 1,25 and $50 \mu \mathrm{g} / \mu \mathrm{L}$ respectively. In this work antimicrobial activity against Lactobacillus aciophilus and Lactobacillus casei was not observed.

Table 3. Berberis goudotii total extract and fractions ( $\mu \mathrm{g} / \mu \mathrm{L})$-Minimum Inhibitory Concentration (MIC) and Bactericidal or Bacteriostatic effects (Minimum Concentration, MBC) *.

\begin{tabular}{|c|c|c|c|c|c|c|c|c|c|c|c|c|}
\hline \multirow{3}{*}{ Microorganism } & \multicolumn{4}{|c|}{ Total Extract $(\mu \mathrm{g} / \mu \mathrm{L})$} & \multicolumn{4}{|c|}{ Hexane Fraction $(\mu \mathrm{g} / \mu \mathrm{L})$} & \multicolumn{4}{|c|}{ Butanol Fraction $(\mu \mathrm{g} / \mu \mathrm{L})$} \\
\hline & \multicolumn{2}{|c|}{ MIC } & \multicolumn{2}{|c|}{ MBC } & \multicolumn{2}{|c|}{ MIC } & \multicolumn{2}{|c|}{ MBC } & \multicolumn{2}{|c|}{ MIC } & \multicolumn{2}{|c|}{ MBC } \\
\hline & Agar $^{1}$ & Broth $^{2}$ & Agar $^{1}$ & Broth $^{2}$ & Agar $^{1}$ & Broth $^{2}$ & Agar ${ }^{1}$ & Broth $^{2}$ & Agar $^{1}$ & Broth $^{2}$ & Agar $^{1}$ & Broth ${ }^{2}$ \\
\hline $\begin{array}{c}\text { Lactobacillus } \\
\text { acidophilus }\end{array}$ & $>32$ & $>32$ & $>32$ & $>32$ & $>32$ & $>32$ & $>32$ & $>32$ & $>32$ & $>32$ & $>32$ & $>32$ \\
\hline Lactobacillus casei & $>32$ & $>32$ & $>32$ & $>32$ & $>32$ & $>32$ & $>32$ & $>32$ & $>32$ & $>32$ & $>32$ & $>32$ \\
\hline Streptococcus mutans & 4 & 1 & $4^{\mathrm{a}}$ & $1^{\mathrm{a}}$ & $>32$ & $>32$ & $>32$ & $>32$ & $>32$ & $>32$ & $>32$ & $>32$ \\
\hline $\begin{array}{l}\text { Streptococcus } \\
\text { sobrinus }\end{array}$ & 4 & 1 & $4^{\mathrm{a}}$ & $1^{\mathrm{a}}$ & $>32$ & $>32$ & $>32$ & $>32$ & $>32$ & $>32$ & $>32$ & $>32$ \\
\hline $\begin{array}{l}\text { Fusobacterium } \\
\text { nucleatum }\end{array}$ & 1 & 0.12 & $1^{b}$ & $0.12^{b}$ & 1 & 1 & $1^{\text {a }}$ & $1^{\mathrm{a}}$ & 1 & 0.12 & $1^{b}$ & $0.12^{b}$ \\
\hline $\begin{array}{l}\text { Porphyromonas } \\
\text { gingivalis }\end{array}$ & 1 & 0.12 & $1^{b}$ & $0.12^{b}$ & 1 & 1 & $1^{\mathrm{a}}$ & $1^{\mathrm{a}}$ & 1 & 0.12 & $1^{b}$ & $0.12^{b}$ \\
\hline Prevotella intermedia & 1 & 0.12 & $1^{b}$ & $0.12^{b}$ & 1 & 1 & $1^{\mathrm{a}}$ & $1^{\mathrm{a}}$ & 1 & 0.12 & $1^{b}$ & $0.12^{b}$ \\
\hline
\end{tabular}

$n=3$ determinations. ${ }^{1}$ Agar diffusion method. ${ }^{2}$ Broth microdilution method. ${ }^{\text {a }}$ Bacd $=$ Bactericidal. ${ }^{\mathrm{b}}$ Bact $=$ Bacteriostatic. $\left({ }^{*}\right)$ Positive control Ceftazidime for cariogenic bacteria (MIC $=0.03 \mu \mathrm{g} / \mu \mathrm{L}$ ) and periodontal bacteria $(\mathrm{MIC}=0.06 \mu \mathrm{g} / \mu \mathrm{L})$

Minimum inhibitory concentration was evaluated by agar diffusion and broth microdilution methods [55,63]. In addition, MBC was determined by performing a new MIC culture by the agar diffusion method [59,62,105]. For Berberis goudotii total extract MIC was determined in decreasing 
concentrations starting at 32 , and decreasing as follows: $16,8,4,2,1$ and $0.5 \mu \mathrm{g} / \mu \mathrm{L}$ on cariogenic bacteria. Additionally, for periodontal disease bacteria concentrations decreased as follows: 4, 2, 1, $0.5,0.25,0.12$ and $0.06 \mu \mathrm{g} / \mu \mathrm{L}$. Differences in concentrations were due to the response for each strain of bacteria evaluated. That is, periodontal bacteria presented greater susceptibility to antimicrobial agents (total extract and fractions) in comparison with cariogenic bacteria.

A higher sensitivity was observed for the microdilution method in broth with values of $0.12 \mu \mathrm{g} / \mu \mathrm{L}$ against all periodontal bacteria assayed, and $1.0 \mu \mathrm{g} / \mu \mathrm{L}$ against some cariogenic bacteria evaluated. In contrast, for evaluating periodontal bacteria by means of agar diffusion method, a MIC value of $1.0 \mu \mathrm{g} / \mu \mathrm{L}$ was the minimum concentration of total extract sufficient to prevent periodontal bacterial growth. A MIC of $4.0 \mu \mathrm{g} / \mu \mathrm{L}$ was required to prevent cariogenic bacteria growth. The difference in sensitivity between methods can be attributed to final inoculum concentration in the microdilution method $\left(10^{6} \mathrm{CFU} / \mathrm{mL}\right)$, which was lower than the concentration for the diffusion method $\left(10^{8}\right.$ $\mathrm{UFC} / \mathrm{mL}$ ). Also, the diffusion phenomenon has an effect since polar compounds diffuse through the agar's mesh, while polar and apolar compounds are in direct contact with the microorganism in the microdilution method $[63,105]$.

Minimum bactericidal concentration showed a bacteriostatic effect against Streptococcus mutans and Streptococcus sobrinus cariogenic bacteria at concentrations of $1.0 \mu \mathrm{g} / \mu \mathrm{L}$ (Broth microdilution method) and $4.0 \mu \mathrm{g} / \mu \mathrm{L}$ (Agar diffusion method). At lower concentrations a bactericidal effect on periodontal disease bacteria Porphyromonas gingivalis, Prevotella intermedia and Fusobacterium nucleatum, was observed at concentrations of $0.12 \mu \mathrm{g} / \mu \mathrm{L}$ (Broth microdilution method) and $1.0 \mu \mathrm{g} / \mu \mathrm{L}$ (Agar diffusion method). According to observed results, Berberis goudotii total extract was ineffective at killing Streptococcus mutans and Streptococcus sobrinus, it only prevented their growth. Thus, although microorganisms remained viable, if treatment were to be suspended, bacteria could recover and proliferate again. On the other hand, Berberis goudotii total extract had a lethal effect against Porphyromonas gingivalis, Prevotella intermedia and Fusobacterium nucleatum [100,114,115].

Berberis goudotii active hexane and butanol fractions antimicrobial activity data, MIC and MBC are summarized in Tables 2 and 3. As was described for total extract, fractions only presented antimicrobial activity when the agar diffusion method per well was employed. No activity was observed when the disk agar diffusion method was used, possibly due to compound fraction retention, as was previously explained [105,112].

Berberis goudotii hexane, dichloromethane, butanol and water fractions did not demonstrate any anticariogenic activity. Nevertheless, only antiperiodontal activity was observed for Berberis goudotii hexane and butanol fractions. Some reports with plant crude active extracts have described biological activity as being lost after the fractioning process, considering that activity is the result of an additive effect of synergy or of structural stabilization between compounds. Thus, at the moment of fractionation, antimicrobial activity is lost [116-118].

Anti-periodontal activities for all evaluated concentrations are presented in Table 3. It was observed for hexane and butanol fractions at 1,25 and $50 \mu \mathrm{g} / \mu \mathrm{L}$, with a better response obtained from the butanol fraction. At a $1.0 \mu \mathrm{g} / \mu \mathrm{L}$ concentration, butanol fraction had RPI of $21.5 \pm 3.6,16.0 \pm 2.6$ and $19.1 \pm 2.7 \%$ against Fusobacterium nucleatum, Porphyromonas gingivalis and Prevotella intermedia, respectively. Whereas, for the hexane fraction at the same concentration $1.0 \mu \mathrm{g} / \mu \mathrm{L}$, RPIs were lower: $12.9 \pm 2.5$ for Fusobacterium nucleatum, $7.9 \pm 1.6$ for Porphyromonas gingivalis and $17.2 \pm 0.9 \%$ for Prevotella intermedia.

As was observed for total extract, MIC and MBC for fractions was determined by agar diffusion and microdilution methods, the latter with the greatest sensitivity, due to lower inoculum concentration and contact phenomenon for all compounds, as aforementioned [105,112]. For hexane and butanol fractions, the MIC by diffusion method was $1.0 \mu \mathrm{g} / \mu \mathrm{L}$, while by the microdilution method they were 1.0 and $0.12 \mu \mathrm{g} / \mu \mathrm{L}$ for hexane and butanol fractions, respectively. The minimal bactericidal concentration effect on periodontal disease associated bacteria was of bacteriostatic type for the hexane fraction at a $1.0 \mu \mathrm{g} / \mu \mathrm{L}$ concentration (Agar diffusion and broth microdilution methods). Similarly, 
a bactericidal type effect was observed for the butanol fraction at concentrations of $1.0 \mu \mathrm{g} / \mu \mathrm{L}$ (Agar diffusion method) and $0.12 \mu \mathrm{g} / \mu \mathrm{L}$ (Broth microdilution method). In other words, the hexane fraction inhibits periodontal disease bacteria proliferation, and thus is a bacteriostatic. In contrast, the butanolic fraction is a bactericidal agent. Collectively, for antimicrobial agents (extract or fraction) bacteriostatic or bactericidal effects mainly depend on their mechanisms of action, molecule types and structures, antimicrobial agent concentration, types of microorganism evaluated, size of the inoculum, time of action and bacterial growth phase $[100,119]$.

Regarding secondary metabolites Palombo et al, Viera et al, Milonova et al, among others, have directly associated plant extracts and fractions antimicrobial activity against oral cavity bacteria with secondary metabolite content, such as phenols, polyphenols, flavonoids, terpenes and alkaloids, among others $[28,120,121]$.

This research pioneered in evaluating Berberis goudotii extracts and fractions anticariogenic and antiperiodontal activities. Furthermore, this is the first report on this species, being an important contribution in the search for new natural products that support Berberis goudotii traditional medicine use for the treatment and prevention of oral cavity diseases, such as caries and periodontal disease. However, it would be desirable to perform further studies on isolated and purified compound antimicrobial activity. Therefore, future studies will be carried out in order to isolate and purify chemical and biological markers.

\section{Conclusions}

Berberis goudotii antimicrobial activity was determined against bacteria associated with caries and periodontal disease. Findings revealed that greater anticariogenic and antiperiodontal activity was observed by the agar diffusion method per well in total extract. In contrast, no antimicrobial activity was recognized when using the disk agar diffusion method. The results indicate that the diffusion method in agar by well was a more suitable assay for plant extract and fractions antimicrobial activity evaluation. Not all Berberis goudotii fractions in different solvents displayed anticariogenic activity. Nevertheless, activity against periodontal disease associated bacteria was observed, where the butanol fraction was the most active, followed by the hexane fraction. The butanol fraction had a bactericidal effect on periodontal microorganisms, while the hexane fraction evidenced a bacteriostatic effect. This work is the first study on Berberis goudotii antimicrobial activity of anticariogenic and antiperiodontal types. Berberis goudotii is a species of the Berberis genus endemic to Colombia. Additionally, this is the first time that phenols, flavonoids, proanthocyanidins, polyphenols and tannins contents have been reported for aerial parts and extract of this plant.

Author Contributions: This article was submitted in partial fulfillment of L.G.S.-C. doctoral thesis. Funding acquisition, S.J.G.-P., C.A.C.-Z. and L.G.S.-C. Conceptualization, S.J.G.-P., P.E.L.-C. and L.G.S.-C. Methodology, P.E.L.-C., F.G. and L.G.S.-C. Resources, S.J.G.-P., C.A.C.-Z. and L.G.S.-C. Formal analysis, C.C.M.-R., P.E.L.-C. and L.G.S.-C. Investigation, C.C.M.-R., C.A.C.-Z. and L.G.S.-C. Writing-original draft, S.J.G.-P., C.A.C.-Z. and L.G.S.-C. Writing-review and editing, F.G., P.E.L.-C. and L.G.S.-C.

Funding: This work was financed by the Academic Vice-Rectory and Vice-Rectory for Research of the Pontificia Universidad Javeriana (Projects 5392, 7341 and 8984) and Administrative Department of Science, Technology, and Innovation (COLCIENCIAS) support.

Acknowledgments: Authors thank María Alejandra Díaz and Nestor García, Biologists at Pontificia Universidad Javeriana for supporting the identification of plant material. At María Lucía Gutiérrez and Martha Margarita González for supporting the revision of the manuscript. Authors manifest their gratitude to Merck, and COLCIENCIAS (Administrative Department of Science, Technology, and Innovation) for financial support of the thesis titled "Phytochemical study of some Colombian native plants and evaluation of its antimicrobial activity and of its remineralizing effect on tooth enamel".

Conflicts of Interest: The authors declare no conflict of interest. 


\section{References}

1. Locker, D. Concepts of oral health, disease and the quality of life. In Measuring Oral Health and Quality of Life; Slade, G.D., Ed.; Department of Dental Ecology, School of Dentistry, University of North Carolina: Chapel Hill, NC, USA, 1997; p. 172.

2. Petersen, P.E. The world oral health report 2003: Continuous improvement of oral health in the 21st century-The approach of the who global oral health programme. Commun. Dent. Oral Epidemiol. 2003, 31 (Suppl. 1), 3-23. [CrossRef]

3. Sheiham, A. Oral health, general health and quality of life. Bull. World Health Org. 2005, 83, 644. [PubMed]

4. Petersen, P.E.; Ogawa, H. The global burden of periodontal disease: Towards integration with chronic disease prevention and control. Periodontology 2000 2012, 60, 15-39. [CrossRef] [PubMed]

5. Guggenheim, B. Streptococci of dental plaques. Caries Res. 1968, 2, 147-163. [CrossRef] [PubMed]

6. Carlsson, J.; Grahnen, H.; Jonsson, G. Lactobacilli and Streptococci in the mouth of children. Caries Res. 1975, 9, 333-339. [CrossRef] [PubMed]

7. Fitzgerald, R.J.; Adams, B.O.; Fitzgerald, D.B.; Knox, K.W. Cariogenicity of human plaque lactobacilli in gnotobiotic rats. J. Dent. Res. 1981, 60, 919-926. [CrossRef] [PubMed]

8. Keyes, P.H. The infectious and transmissible nature of experimental dental caries. Findings and implications. Arch. Oral Boil. 1960, 1, 304-320. [CrossRef]

9. Gamboa, F.; Lamby, C.P.; Gómez, O.L.; Chaves, M.; Plazas, L.A.; Arévalo, A.; García, D.A.; Sarralde, A.L. Aspectos ecológicos orales, conocimiento microbiológico y molecular de microorganismos de importancia en caries dental y periodontitis crónica. In Experiencias y Resultados de Investigación en Odontología, 1st ed.; Roa-Molina, N.E., Ed.; Editorial Pontificia Universidad Javeriana: Bogotá, Colombia, 2018; Volume 1, p. 344.

10. Selwitz, R.H.; Ismail, A.I.; Pitts, N.B. Dental caries. Lancet 2007, 369, 51-59. [CrossRef]

11. Kassebaum, N.J.; Bernabe, E.; Dahiya, M.; Bhandari, B.; Murray, C.J.; Marcenes, W. Global burden of severe tooth loss: A systematic review and meta-analysis. J. Dent. Res. 2014, 93, 20s-28s. [CrossRef]

12. Armitage, G.C. Development of a classification system for periodontal diseases and conditions. Ann. Periodontal. 1999, 4, 1-6. [CrossRef]

13. Socransky, S.S.; Haffajee, A.D. The bacterial etiology of destructive periodontal disease: Current concepts. J. Periodontal. 1992, 63, 322-331. [CrossRef]

14. Marinho, V.C.C.; Higgins, J.; Logan, S.; Sheiham, A. Fluoride toothpastes for preventing dental caries in children and adolescents. Cochrane Database Syst. Rev. 2003. [CrossRef] [PubMed]

15. Marinho, V.C.C.; Worthington, H.V.; Walsh, T.; Chong, L.Y. Fluoride gels for preventing dental caries in children and adolescents. Cochrane Database Syst. Rev. 2015. [CrossRef] [PubMed]

16. Ismail, A.I.; Tellez, M.; Pitts, N.B.; Ekstrand, K.R.; Ricketts, D.; Longbottom, C.; Eggertsson, H.; Deery, C.; Fisher, J.; Young, D.A.; et al. Caries management pathways preserve dental tissues and promote oral health. Commun. Dent. Oral Epidemiol. 2013, 41, e12-e40. [CrossRef] [PubMed]

17. Pitts, N.B.; Ekstrand, K.R. International caries detection and assessment system (icdas) and its international caries classification and management system (iccms)-Methods for staging of the caries process and enabling dentists to manage caries. Commun. Dent. Oral Epidemiol. 2013, 41, e41-e52. [CrossRef] [PubMed]

18. Socransky, S.S.; Haffajee, A.D. Dental biofilms: Difficult therapeutic targets. Periodontology 2000 2002, 28, 12-55. [CrossRef] [PubMed]

19. Teles, R.P.; Haffajee, A.D.; Socransky, S.S. Microbiological goals of periodontal therapy. Periodontology 2000 2006, 42, 180-218. [CrossRef] [PubMed]

20. Lombardo, G.; Signoretto, C.; Corrocher, G.; Pardo, A.; Pighi, J.; Rovera, A.; Caccuri, F.; Nocini, P.F. A topical desiccant agent in association with ultrasonic debridement in the initial treatment of chronic periodontitis: A clinical and microbiological study. New Microbial. 2015, 38, 393-407.

21. Bracke, J.; Basara, M.; Savord, E.; Dunaway, A.; Watkins, M. Pilot evaluation of a simple adjunctive method for improved removal of oral biofilm during conventional scaling and root planing therapy. J. Boil. Regul. Homeost. Agents 2015, 29, 6-9.

22. Isola, G.; Matarese, G.; Williams, R.C.; Siciliano, V.I.; Alibrandi, A.; Cordasco, G.; Ramaglia, L. The effects of a desiccant agent in the treatment of chronic periodontitis: A randomized, controlled clinical trial. Clin. Oral Invest. 2018, 22, 791-800. [CrossRef] 
23. Laugisch, O.; Ramseier, C.A.; Salvi, G.E.; Hagi, T.T.; Burgin, W.; Eick, S.; Sculean, A. Effects of two different post-surgical protocols including either $0.05 \%$ chlorhexidine herbal extract or $0.1 \%$ chlorhexidine on post-surgical plaque control, early wound healing and patient acceptance following standard periodontal surgery and implant placement. Clin. Oral Invest. 2016, 20, 2175-2183.

24. Matarese, G.; Ramaglia, L.; Cicciu, M.; Cordasco, G.; Isola, G. The effects of diode laser therapy as an adjunct to scaling and root planing in the treatment of aggressive periodontitis: A 1-year randomized controlled clinical trial. Photomed. Laser Surg. 2017, 35, 702-709. [CrossRef] [PubMed]

25. Sharma, D.; Singh, A.; Verma, K.; Paliwal, S.; Sharma, S.; Dwivedi, J. Fluoride: A review of pre-clinical and clinical studies. Environ. Toxicol. Pharmacol. 2017, 56, 297-313. [CrossRef] [PubMed]

26. Ullah, R.; Zafar, M.S.; Shahani, N. Potential fluoride toxicity from oral medicaments: A review. Iran. J. Basic Med. Sci. 2017, 20, 841-848. [PubMed]

27. Henley-Smith, C.J.; Steffens, F.E.; Botha, F.S.; Lall, N. Predicting the influence of multiple components on microbial inhibition using a logistic response model-A novel approach. BMC Complement. Altern. Med. 2014, 14, 190. [CrossRef] [PubMed]

28. Milovanova-Palmer, J.; Pendry, B. Is there a role for herbal medicine in the treatment and management of periodontal disease? J. Herb. Med. 2018, 12, 33-48. [CrossRef]

29. Rios, J.L.; Recio, M.C. Medicinal plants and antimicrobial activity. J. Ethnopharmacol. 2005, 100, 80-84. [CrossRef] [PubMed]

30. Katsura, H.; Tsukiyama, R.I.; Suzuki, A.; Kobayashi, M. In vitro antimicrobial activities of Bakuchiol against oral microorganisms. Antimicrob. Agents Chemother. 2001, 45, 3009-3013. [CrossRef]

31. Hwang, J.K.; Chung, J.Y.; Baek, N.I.; Park, J.H. Isopanduratin a from Kaempferia pandurata as an active antibacterial agent against cariogenic streptococcus mutans. Int. J. Antimicrob. Agents 2004, 23, 377-381. [CrossRef]

32. Akhalwaya, S.; van Vuuren, S.; Patel, M. An in vitro investigation of indigenous south african medicinal plants used to treat oral infections. J. Ethnopharmacol. 2018, 210, 359-371. [CrossRef]

33. Gamboa, F.; Muñoz, C.-C.; Numpaque, G.; Sequeda-Castañeda, L.G.; Gutierrez, S.J.; Tellez, N. Antimicrobial activity of Piper marginatum Jacq and Ilex guayusa Loes on microorganisms associated with periodontal disease. Int. J. Microbiol. 2018, 2018, 9. [CrossRef] [PubMed]

34. Bussmann, R.W.; Paniagua Zambrana, N.Y.; Romero, C.; Hart, R.E. Astonishing diversity-The medicinal plant markets of bogotá, colombia. J. Ethnobiol. Ethnomed. 2018, 14, 43. [CrossRef] [PubMed]

35. Bernal, H.Y.; García-Martínez, H.; Quevedo-Sánchez, G.F. Pautas Para el Conocimiento, Conservación y uso Sostenible de las Plantas Medicinales Nativas en Colombia; Ministerio de Ambiente, Vivienda y Desarrollo Territorial e Instituto de Investigación de Recursos Biológicos Alexander von Humboldt: Bogotá, Colombia, 2011; p. 232.

36. García-Barriga, H. Berberis rigidifolia. In Flora Medicinal de Colombia. Botánica Médica; Imprenta Nacional: Bogotá, Colombia, 1974; Volume I, pp. 314-317.

37. Marín, C.; Parra, S. Bitácora de Flora: Guía Visual de Plantas de Páramos en Colombia; Instituto de Investigación de Recursos Biológicos Alexander von Humboldt: Bogotá, Colombia, 2015.

38. Sequeda-Castañeda, L.G.; Célis, C.; Gutiérrez, S.; Luengas-Caicedo, P.E. Berberis rigidifolia Kunth. (Berberidaceae) Colombian endemic plant. PhOL 2016, 2016, 134-138.

39. Díaz, M.A.; Moreno-Castro, J.D.; Sequeda-Castañeda, L.G. Berberis Goudotii-Pictures; Editorial PUJ: Bogotá, Colombia, 2014.

40. Method 2.9.35 —Powder fineness. Available online: https://www.drugfuture.com/Pharmacopoeia/EP7/ DATA/20934E.PDF (accessed on 4 February 2017).

41. Parimelazhagan, T. Pharmacological Assays of Plant-Based Natural Products; Springer International Publishing: Basel, Switzerland, 2016; Volume 71.

42. Sharapin, N. Fundamentos de Tecnología de Productos Fitoterapéuticos; Convenio Andrés Bello: Santafé de Bogotá, Colombia, 2000.

43. WHO. Quality Control Methods for Herbal Materials; World Health Organization: Geneva, Switzerland, 2011; p. 187.

44. Carvajal-Rojas, L.; Hata-Uribe, Y.; Sierra-Martínez, N.; Rueda-Niño, D. Análisis fitoquímico preliminar de hojas, tallos y semillas de cupatá (Strychnos schultesiana krukoff). Colomb. For. 2009, 12, 161-170. [CrossRef]

45. Domínguez, X.A. Métodos de Investigación Fitoquímica; Limusa: Ciudad de México, México, 1988. 
46. Tiwari, P.; Kumar, B.; Kaur, M.; Kaur, G.; Kaur, H. Phytochemical screening and extraction: A review. Int. Pharm. Sci. 2011, 1, 98-106.

47. Wagner, H.; Bladt, S. Plant Drug Analysis: A Thin Layer Chromatography Atlas; Springer-Verlag Berlin Heidelberg: Munich, Germany, 1996.

48. Lock, O.R. Invetigacion Fitoquimica. Métodos en el Estudio de Productos Naturales; Fondo Editorial de la Pontifiicia Universidad Católica del Perú: Lima, Perú, 2016.

49. ANVISA. Farmacopeia brasileira-Taninos totais. In Volume 2-Monografias; Agência Nacional de Vigilância Sanitária-Fundação Oswaldo Cruz: Brasília, Brasil, 2010; p. 899.

50. Luengas-Caicedo, P.E.; Braga, F.C.; Brandão, G.C.; Oliveira, A.B. Seasonal and intraspecific variation of flavonoids and proanthocyanidins in Cecropia glaziovi Sneth. leaves from native and cultivated specimens. Z. Naturforsch. C 2007, 62, 701-709. [CrossRef]

51. Isaza, J.H.; Veloza, L.A.; Guevara, C.A.; Ávila, Y.P.; Díaz, O. A spectrometric approach to the phenoltotals in species of melastomataceae familiy. Actual. Biol. 2005, 27, 75-79.

52. Palomino, L.R.; García, C.M.; Gil, J.H.; Rojano, B.A.; Durango, D.L. Determination of phenolic content and evaluation of antioxidant activity of propolis from antioquia (colombia). Vitae 2009, 16, 388-395.

53. Luengas-Caicedo, P.E. Contribuição para a Padronização de Extratos de Folhas de Cecropia Glaziovii Snethl: Estudos de Variação Sazonal e Intra-Específica de Flavonóides e Proantocianidinas, de Metodologias de Extração e de Atividade Vasorelaxante; Universidade Federal de Minas Gerais: Belo Horizonte, Brazil, 2005.

54. Hiermann, A.; Karting, T.; Azzam, S. Ein beitrag zur quantitativen bestimmung der procyanidine in crataegus. Sci. Pharm. 1986, 54, 331-337.

55. Balouiri, M.; Sadiki, M.; Ibnsouda, S.K. Methods for in vitro evaluating antimicrobial activity: A review. J. Pharm. Anal. 2016, 6, 71-79. [CrossRef]

56. Cavalieri, S.J.; Rankin, I.D.; Harbeck, R.J.; Sautter, R.L.; McCarter, Y.S.; Sharp, S.E.; Ortez, J.H.; Spiegel, C.A. Manual of Antimicrobial Susceptibility Testing; American Society for Microbiology: Washington, DC, USA, 2009; p. 240.

57. CLSI. Performance Standards for Antimicrobial Disk Susceptibility Tests; Approved Standard-Tenth Edition; Clinical and Laboratory Standards Institute: Wayne, PA, USA, 2009.

58. CLSI. Methods for Antimicrobial Susceptibility Testing of Anaerobic Bacteria; Approved Standard-Eighth Edition; Clinical and Laboratory Standards Institute: Wayne, PA, USA, 2012.

59. Schwalbe, R.; Steele-Moore, L.; Goodwin, A.C. Antimicrobial Susceptibility Testing Protocols; CRC Press: Boca Raton, FL, USA, 2007.

60. CLSI. Performance Standard for Antimicrobial Susceptibility Testing; Clinical and Laboratory Standards Institute: Wayne, PA, USA, 2007.

61. Ramirez, L.S.; Díaz, H.E. Actividad antibacteriana de extractos y fracciones del ruibardo (Rumex conglomeratus). Sci. Tech. 2007, 23. [CrossRef]

62. Bonev, B.; Hooper, J.; Parisot, J. Principles of assessing bacterial susceptibility to antibiotics using the agar diffusion method. J. Antimicrob. Chemother. 2008, 61, 1295-1301. [CrossRef] [PubMed]

63. Wiegand, I.; Hilpert, K.; Hancock, R.E. Agar and broth dilution methods to determine the Minimal Inhibitory Concentration (MIC) of antimicrobial substances. Nat. Protoc. 2008, 3, 163-175. [CrossRef]

64. Bonilla, D.M.; Mendoza, Y.; Moncada, C.E.; Murcia, O.; Rojas, Á.P.; Calle, J.; Pinzón, R.; Neiro, L. Efecto del aceite esencial de Rosmarinus officinalis sobre Porphyromonas gingivalis cultivada in vitro. Rev. Colomb. Cienc. Quím. Farm. 2016, 45, 275. [CrossRef]

65. CLSI. Methods for Determining Bactericidal Activity of Antimicrobial Agents, 1st ed.; Clinical and Laboratory Standards Institute: Wayne, PA, USA, 1999.

66. Franco-Ospina, L.A.; Matiz-Melo, G.E.; Pájaro-Bolívar, I.B.; Gómez-Estrada, H.A. In vitro antibacterial activity of extracts and fractions of Physalis peruviana L. and Caesalpinia pulcherrima (L.) Swartz. Bol. Latinoam. Caribe. Plant. Med. Aromat. 2013, 12, 230-237.

67. Lesaffre, E.; Feine, J.; Leroux, B.; Declerck, D. Statistical and Methodological Aspects of Oral Health Research; Wiley: Hoboken, NJ, USA, 2009.

68. Di Rienzo, J.A.; Casanoves, F.; Balzarini, M.G.; Gonzalez, L.; Tablada, M.; Robledo, C.W. Infostat. Available online: http:/ / www.infostat.com.ar / (accessed on 9 August 2018).

69. Ekstrom, C.; Sørensen, H. Introduction to Statistical Data Analysis for the Life Sciences; CRC Press Taylor \& Francis: Boca Raton, FL, USA, 2015. 
70. Jones, D. Pharmaceutical Statistics; Pharmaceutical Press: London, UK, 2002.

71. Belwal, T.; Giri, L.; Bhatt, I.D.; Rawal, R.S.; Pande, V. An improved method for extraction of nutraceutically important polyphenolics from Berberis jaeschkeana c.K. Schneid. Fruits. Food Chem. 2017, 230, 657-666. [CrossRef] [PubMed]

72. Zovko Koncic, M.; Kremer, D.; Karlovic, K.; Kosalec, I. Evaluation of antioxidant activities and phenolic content of Berberis vulgaris L. and Berberis croatica Horvat. Food Chem. 2010, 48, 2176-2180. [CrossRef] [PubMed]

73. Azuola, R.; Vargas, P. Extracción de Sustancias Asistida por Ultrasonido (EUA). Tecnol. Marcha 2007, 20, 30-40.

74. Londoño-Londoño, J.A. Aprovechamiento de residuos de la agroindustria de cítricos: Extracción y caracterización de flavonoides. In Cítricos: Cultivo, Poscosecha e Industrialización; Corporación Universitaria Lasallista: Caldas, Antioquia, 2011; pp. 395-416.

75. Vardanega, R.; Santos, D.T.; Meireles, M.A.A. Intensification of bioactive compounds extraction from medicinal plants using ultrasonic irradiation. Pharmacogn. Rev. 2014, 8, 88-95.

76. Chan, C.H.; See, T.Y.; Yusoff, R.; Ngoh, G.C.; Kow, K.W. Extraction of bioactives from Orthosiphon stamineus using microwave and ultrasound-assisted techniques: Process optimization and scale up. Food Chem. 2017, 221, 1382-1387. [CrossRef]

77. Falleh, H.; Ksouri, R.; Lucchessi, M.E.; Abdelly, C.; Magné, C. Ultrasound-assisted extraction: Effect of extraction time and solvent power on the levels of polyphenols and antioxidant activity of Mesembryanthemum edule L. Aizoaceae shoots. Trop. J. Pharm. Res. 2012, 11. [CrossRef]

78. Khemakhem, I.; Ahmad-Qasem, M.H.; Catalan, E.B.; Micol, V.; Garcia-Perez, J.V.; Ayadi, M.A.; Bouaziz, M. Kinetic improvement of olive leaves' bioactive compounds extraction by using power ultrasound in a wide temperature range. Ultrason. Sonochem. 2017, 34, 466-473. [CrossRef] [PubMed]

79. Liu, Z.; Mo, K.; Fei, S.; Zu, Y.; Yang, L. Efficient approach for the extraction of proanthocyanidins from Cinnamomum Longepaniculatum leaves using ultrasonic irradiation and an evaluation of their inhibition activity on digestive enzymes and antioxidant activity in vitro. J. Sep. Sci. 2017, 40, 3100-3113. [CrossRef] [PubMed]

80. Shirsath, S.R.; Sonawane, S.H.; Gogate, P.R. Intensification of extraction of natural products using ultrasonic irradiations-A review of current status. Chem. Eng. Process. Process Intensif. 2012, 53, 10-23. [CrossRef]

81. Qadir, S.A.; Kwon, M.C.; Han, J.G.; Ha, J.H.; Chung, H.S.; Ahn, J.; Lee, H.Y. Effect of different extraction protocols on anticancer and antioxidant activities of Berberis koreana bark extracts. J. Biosci. Bioeng. 2009, 107, 331-338. [CrossRef] [PubMed]

82. Rizvi, S.S.H. Separation, Extraction and Concentration Processes in the Food, Beverage and Nutraceutical Industries; Elsevier Science: Amsterdam, The Netherlands, 2010.

83. Bonesi, M.; Loizzo, M.R.; Conforti, F.; Passalacqua, N.G.; Saab, A.; Menichini, F.; Tundis, R. Berberis aetnensis and $\mathrm{b}$. Libanotica: A comparative study on the chemical composition, inhibitory effect on key enzymes linked to Alzheimer's disease and antioxidant activity. J. Pharm. Pharmacol. 2013, 65, 1726-1735. [CrossRef] [PubMed]

84. Alamzeb, M.; Khan, M.R.; Mamoon Ur, R.; Ali, S.; Khan, A.A. Isolation, structure elucidation and enzyme inhibition studies of a new hydroxy ester and other compounds from berberis jaeschkeana schneid stem. Nat. Prod. Res. 2015, 29, 1664-1669. [CrossRef] [PubMed]

85. Alarcon, D.; Paredes, M.; Ramos, D.; Gonzalez, K.; Díaz, R.; Núñez, D. Aqueous and methanol extracts of Berberis darwinii h. (Berberidaceae) inhibit innate celular responses in human monocytes in vitro treated. Bol. Latinoam. Caribe. Plant. Med. Aromat. 2014, 13, 81-91.

86. Quevedo, R.; Antolinez, S.; Moreno, B.; Fajardo, V. Tabienina a: Un nuevo alcaloide aporfinabencilisoquinolina oxidado. Sci. Tech. 2007, 13, 167-169.

87. Quevedo, R.; Núñez, L.; Moreno, B. A rare head-head binding pattern in bisbenzylisoquinoline alkaloids. Nat. Prod. Res. 2011, 25, 934-938. [CrossRef]

88. Bhardwaj, D.; Kaushik, N. Phytochemical and pharmacological studies in genus Berberis. Phytochemistry Reviews 2013, 11, 523-542. [CrossRef]

89. Khan, I.; Najeebullah, S.; Ali, M.; Shinwari, Z. Phytopharmacological and ethnomedicinal uses of the genus Berberis (Berberidaceae): A review. Trop. J. Pharm. Res. 2016, 15, 2047-2057. [CrossRef] 
90. Manosalva, L.; Mutis, A.; Díaz, J.; Urzúa, A.; Fajardo, V.; Quiroz, a. Identification of isoquinoline alkaloids from Berberis microphylla by HPLC ESI-MS/MS. Bol. Latinoam. Caribe. Plant. Med. Aromat. 2014, 13, 323-334.

91. Martínez, J.L.; Russo, A.; Vinet, R.; Jaimes, L.; Russo, L.; Laurido, C. Berberis chilensis gillies ex Hook: Alkaloids and pharmacologiacl activities. Pharmacologyonline 2018, 1, 58-67.

92. Mokhber-Dezfuli, N.; Saeidnia, S.; Gohari, A.R.; Kurepaz-Mahmoodabadi, M. Phytochemistry and pharmacology of Berberis species. Pharmacogn. Rev. 2014, 8, 8-15. [PubMed]

93. Rahimi-Madiseh, M.; Lorigoini, Z.; Zamani-Gharaghoshi, H.; Rafieian-Kopaei, M. Berberis vulgaris: Specifications and traditional uses. Iran. J. Basic Med. Sci. 2017, 20, 569-587.

94. Sabir, S.; Tahir, K.; Rashid, N.; Naz, S.; Masood, B.; Shah, M.A. Phytochemical and antioxidant studies of Berberis lycium. Pak. J. Pharm. Sci. 2013, 26, 1165-1172.

95. Arena, M.E.; Postemsky, P.D.; Curvetto, N.R. Changes in the phenolic compounds and antioxidant capacity of Berberis microphylla g. Forst. berries in relation to light intensity and fertilization. Sci. Hortic. 2017, 218, 63-71. [CrossRef]

96. Belwal, T.; Bhatt, I.D.; Rawal, R.S.; Pande, V. Microwave-Assisted Extraction (MAE) conditions using polynomial design for improving antioxidant phytochemicals in Berberis asiatica Roxb. Ex DC. Leaves. Ind. Crops Prod. 2017, 95, 393-403. [CrossRef]

97. Furrianca, M.C.; Alvear, M.; Zambrano, T.; Fajardo, V.; Salazar, L.A. Phytochemical constituents of the root of Berberis microphylla. Asian J. Pharm. Clin. Res. 2017, 10, 225-227. [CrossRef]

98. Cowan, M.M. Plant products as antimicrobial agents. Clin. Microbiol. Rev. 1999, 12, 564-582. [CrossRef] [PubMed]

99. Pandey, A.K.; Kumar, S. Perspective on plant products as antimicrobials agents: A review. Pharmacologia 2013, 4, 469-480. [CrossRef]

100. Paredes, F.; Roca, J.J. Acción de los antibióticos. Offarm 2004, 23, 116-124.

101. Molina-López, J. Terapéutica. Drogas Antibacterianas. Available online: http://www.facmed.unam.mx/ deptos/microbiologia/bacteriologia/terapeutica.html (accessed on 15 November 2018).

102. Olsson-Liljequist, B.; Nord, C.E. Methods for susceptibility testing of anaerobic bacteria. Clin. Infect. Dis. 1994, 18, S293-S296. [CrossRef] [PubMed]

103. Atta-ur-Rahman. Studies in natural products chemistry. In Methods for Evaluating Antimicrobial Activity of Plant Extracts; Elsevier Science: Amsterdam, The Netherlands, 2016; Volume 47.

104. CYTED. Manual de técnicas de investigación. Proyecto X-1: Búsqueda de principios bioactivos en plantas de la región. In Programa Iberoamericano de Ciencia y Tecnología para el Desarrollo; Comité científico: Madrid, España, 1995.

105. Ramirez, L.S.; Marin-Castaño, D. Metodologias para evaluar in vitro la actividad antibacteriana de compuestos de origen vegetal. Sci. Tech. 2009, XV, 263-268.

106. Rios, J.L.; Recio, M.C.; Villar, A. Screening methods for natural products with antimicrobial activity: A review of the literature. J. Ethnopharmacol. 1988, 23, 127-149. [CrossRef]

107. Atkins, P.; de Paula, J. Atkins' Physical Chemistry; OUP Oxford: Oxford, UK, 2010.

108. Valgas, C.; Souza, S.M.d.; Smânia, E.F.A.; Smânia, A., Jr. Screening methods to determine antibacterial activity of natural products. Braz. J. Microbiol. 2007, 38, 369-380. [CrossRef]

109. Ortíz-Ardila, A.E.; Correa-Cuadros, J.P.; Celis-Zambrano, C.A.; Rodríguez-Bocanegra, M.X.; Robles-Camargo, J.; Sequeda-Castañeda, L.G. Antioxidant and antimicrobial capacity Cecropia mutisiana Mildbr. (cecropiaceae) leave extracts. Emir. J. Food Agric. 2017, 29, 25-35. [CrossRef]

110. Das, K.; Tiwari, R.K.S.; Shrivastava, D.K. Techniques for evaluation of medicinal plant products as antimicrobial agents: Current methods and future trends. J. Med. Plant. Res. 2010, 4, 104-111.

111. Eloff, J.N. A sensitive and quick microplate method to determine the minimal inhibitory concentration of plant extracts for bacteria. Planta Med. 1998, 64, 711-713. [CrossRef]

112. Othman, M.; Loh, H.S.; Wiart, C.; Khoo, T.J.; Lim, K.H.; Ting, K.N. Optimal methods for evaluating antimicrobial activities from plant extracts. J. Microbiol. Methods 2011, 84, 161-166. [CrossRef] [PubMed]

113. Bona, E.A.M.D.; Pinto, F.G.d.S.; Fruet, T.K.; Jorge, T.C.M.; Moura, A.C.d. Comparação de métodos para avaliação da atividade antimicrobiana e determinação da concentração inibitória mínima (cim) de extratos vegetais aquosos e etanólicos. Arq. Inst. Biol. 2014, 81, 218-225. [CrossRef] 
114. Bernatova, S.; Samek, O.; Pilat, Z.; Sery, M.; Jezek, J.; Jakl, P.; Siler, M.; Krzyzanek, V.; Zemanek, P.; Hola, V.; et al. Following the mechanisms of bacteriostatic versus bactericidal action using Raman spectroscopy. Molecules 2013, 18, 13188-13199. [CrossRef] [PubMed]

115. Pankey, G.A.; Sabath, L.D. Clinical relevance of bacteriostatic versus bactericidal mechanisms of action in the treatment of gram-positive bacterial infections. Clin. Infect. Dis. 2004, 38, 864-870. [CrossRef] [PubMed]

116. Turner, P.; Padgham, C.; Hedges, A. Clinical pharmacology \& therapeutics. In Proceedings of the Plenary Lectures Symposia and Therapeutic Sessions of the First World Conference on Clinical Pharmacology \& Therapeutics, London, UK, 3-9 August 1980.

117. Liu, Z. Preparation of botanical samples for biomedical research. Endocr. Metab. Immune Disord. Drug Targets 2008, 8, 112-121. [CrossRef] [PubMed]

118. Atanasov, A.G.; Waltenberger, B.; Pferschy-Wenzig, E.-M.; Linder, T.; Wawrosch, C.; Uhrin, P.; Temml, V.; Wang, L.; Schwaiger, S.; Heiss, E.H.; et al. Discovery and resupply of pharmacologically active plant-derived natural products: A review. Biotechnol. Adv. 2015, 33, 1582-1614. [CrossRef]

119. Haloui, T.; Farah, A.; Balouiri, M.; Chraibi, M.; Fadil, M.; Benbrahim, K.F.; Alaoui, A.B. Bacteriostatic and bactericidal profile of leaves and twigs essential oils of moroccan Pistacia lentiscus L. J. Appl. Pharm. Sci. 2015, 5, 50-53. [CrossRef]

120. Vieira, D.R.P.; Amaral, F.M.M.; Maciel, M.C.G.; Nascimento, F.F.R.F.; Libério, A.S. Plantas e constituintes químicos empregados em odontologia: Revisão de estudos etnofarmacológicos e de avaliação da atividade antimicrobiana in vitro em patógenos orais. Rev. Bras. Plant. Med. 2014, 16, 135-167. [CrossRef]

121. Palombo, E.A. Traditional medicinal plant extracts and natural products with activity against oral bacteria: Potential application in the prevention and treatment of oral diseases. Evid. Based Complement. Altern. Med. 2011, 2011, 15. [CrossRef]

(C) 2019 by the authors. Licensee MDPI, Basel, Switzerland. This article is an open access article distributed under the terms and conditions of the Creative Commons Attribution (CC BY) license (http:/ / creativecommons.org/licenses/by/4.0/). 